\title{
Volcanic evolution of São Vicente, Cape Verde Islands: The Praia Grande landslide
}

\author{
E. Ancochea , M.J. Huertas , F. Hernán , J.L. Brändle
}

Keywords:

Cape Verde Islands

dikes

volcano evolution

giant lateral collapse

\begin{abstract}
A B S T R A C T
The island of São Vicente has undergone continuous volcanic activity from Pliocene to Pleistocene times. The earliest evidence of activity corresponds to some 9 million years ago when a submarine edifice of alkaline basaltic affinity had already started to develop. The island resulted from the growth of a single major edifice (the São Vicente Edifice) built up in several distinguishable growth stages. The early main stage occurred at 6.5 to $4.5 \mathrm{Ma}$ giving rise to an edifice of about $10-12 \mathrm{~km}$ in radius and more than $2500 \mathrm{~m}$ in height whose centre was located south of the present city of Mindelo. Although the edifice in its earlier phase showed typical characteristics of a shield volcano (the Mindelo Formation) it adopted later on those of an ordinary composite volcano (the Madeiral-Monte Cara Formation).

A giant landslide event, the Praia Grande landslide, destroyed the NE sector of the edifice and left a $10 \times 12 \mathrm{~km}$ large depression that was successively refilled by nephelinitic lava flows and some associated carbonatites (the Monte Verde Formation, 4.5-3.1 Ma). The volcanic activity ceased about 3-2 Ma ago when the edifice started to be deeply eroded until disappearing about $90 \%$ of its total volume. Only in recent times $(0.3 \mathrm{Ma})$ very scarce and local strombolian activity has been developed aside the São Vicente Edifice, in the eastern sector of the island.
\end{abstract}

\section{Introduction}

The Cape Verde Archipelago consisting of ten main islands and several islets is located between 550 and $800 \mathrm{~km}$ west of the Senegal coast. The size of the islands varies markedly from the small uninhabited Santa Luzia $\left(35 \mathrm{~km}^{2}\right)$ to the largest Santiago $\left(991 \mathrm{~km}^{2}\right)$.

The Cape Verde Islands display a westward opened horseshoeshaped arrangement. Those located to the north constitute the Barlovento (windward) Line and those extending southward the Sotavento (leeward) Line (Fig. 1). In both island chains the easternmost islands are deeply eroded and are also apparently older. In contrast, the westernmost islands showing a prominent relief seem to be younger. Fogo concentrates at present the Cape Verde volcanic activity (the last eruption in 1995). However, this apparent progression of the volcanic activity is not sufficiently well documented by either field or geochronological data (Griffiths et al., 1975; Mitchell et al., 1983; Jorgensen and Holm, 2002; Plesner et al, 2002; Torres et al, 2002), in contrast, Holm et al. (2008) have recently proved that the islands lying nearly parallel to the African coast (Sal, Boa Vista and Maio) have been active during the Miocene, whereas the remaining ones with a more western site have been built up essentially in the Pliocene and the Pleistocene.
The first geological description of the archipelago, published by Bebiano (1932) represented an important reference to later studies. More detailed investigation and the first mapping works were essentially carried out in the $1960-1970$ s by Portuguese geologists of the Junta de Investigaçoes do Ultramar (Machado and Torre de Assuncao, 1965; Torre de Assunçao and Canilho, 1965; Serralheiro, 1966; Torre de Assunçao et al., 1967; Machado et al., 1968; Serralheiro, 1970, 1976; Mitchell-Thomé, 1976). Recently, the studies dealing with the compositional characteristic of the islands and/or the nature of their magma sources have provided a more accurate picture of the Cape Verde volcanism (i.e.: Davies et al., 1989; Christensen et al., 2001; Doucelance et al., 2003; Escrig et al., 2005; Holm et al., 2006; Dyhr and Holm, 2010), but the progress in the knowledge of the particular geological and volcanological evolution of each of the islands is much less significant.

The oldest unit in many of the islands, the so called "Complexo Eruptivo Interno Antigo" (old internal eruptive complex), consists of submarine volcanics and plutonic intrusions crosscut both by a dense dike swarm. The island of Maio is the only one in which 130 Ma old oceanic crust and sediments are exposed (Serralheiro, 1970; De Paepe et al., 1974; Stillman et al., 1982).

Over that complex, important successions of lava flows built up the main volcanic edifices of the islands, which are still observable on the less eroded ones. This unit, designated as the "Complexo Eruptivo Principal" (main eruptive complex) by the Portuguese geologists is equivalent to the Old Edifices (or volcanic complexes) on the Canary Islands (Ancochea et al., 1991, 1996) and or to the Hawaii shield stage (Peterson and Moore, 1987). 


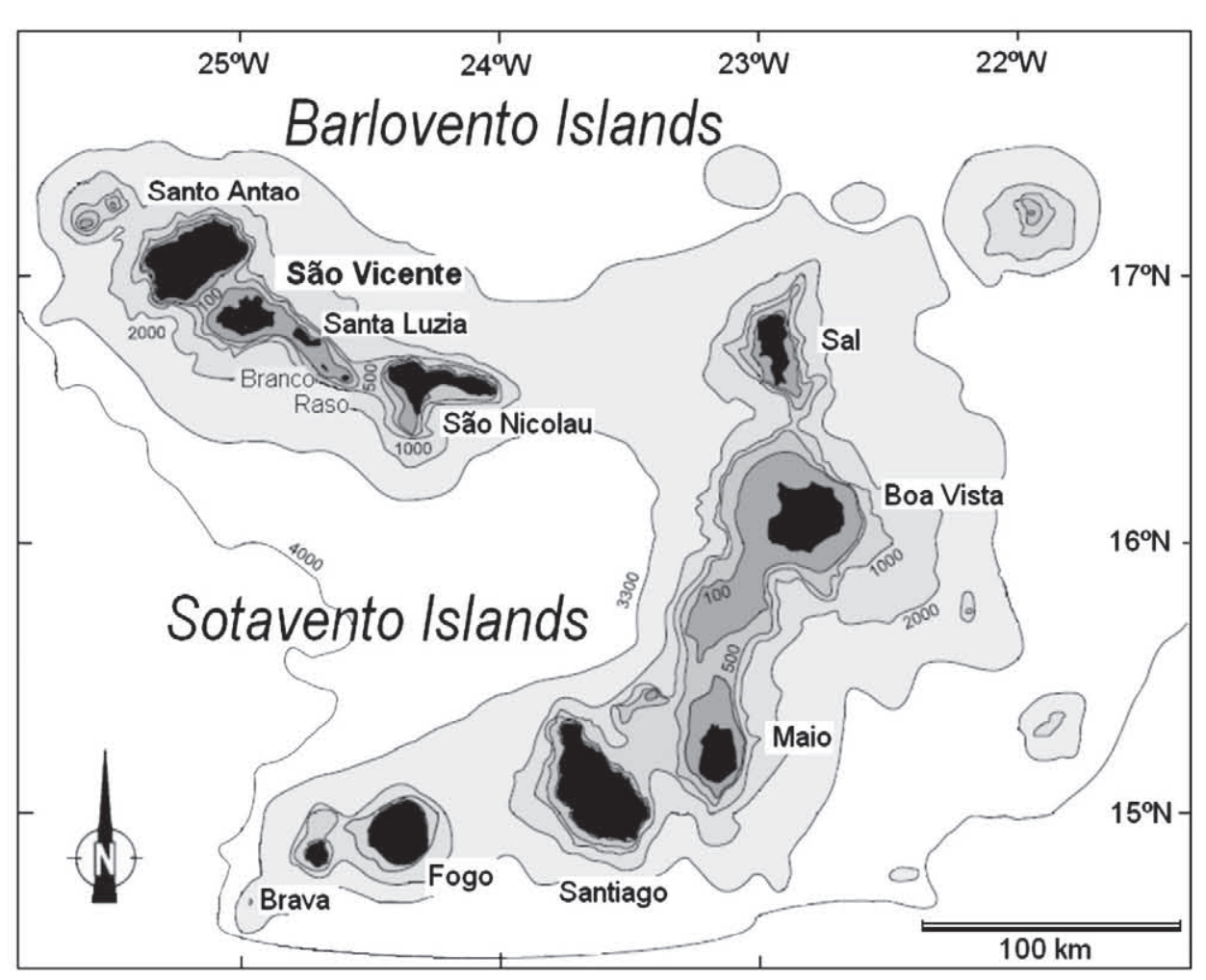

Fig. 1. Distribution and bathymetric map of the Cape Verde Islands. Modified after Holm et al., 2008.

The evolutionary model for São Vicente proposed in this work includes volcano-stratigraphical, petrological, geochemical, structural, geomorphological and geo-chronological data obtained along extensive field work carried out on the island.

Measurements of strike, dip, width and density of about 1000 dikes grouped in almost 100 stations have been made. Major and trace element concentrations were determined by ACTLABS in Ontario (Canada) by X-ray fluorescence spectrometry and inductively coupled plasma-mass spectrometry (ICP-MS).

The material used for dating was represented by "whole rock" samples of 1 or $2 \mathrm{~g}$, with particle size varying from 0.3 to $1 \mathrm{~mm}$. Phenocrysts were removed from the most porphyritic rock samples, using only rock groundmass for the analysis. Samples were dated by the $\mathrm{K} / \mathrm{Ar}$ method by Mass Spec. Services (USA). Argon was extracted by fusion after degassing at moderate temperature in high vacuum and the ${ }^{38} \mathrm{Ar}$ tracer was added to the analysis using a continuous pipetting system. The analytical errors were calculated according to the method of Dalrymple and Lanphere (1969). Converted ages were calculated using the following constants: ${ }^{40} \mathrm{~K} / \mathrm{K}=1.167 \times 10^{-2}$ at\%; $\lambda \varepsilon=0.581 \times$ $10^{-10} \mathrm{yr}^{-1} ; \lambda_{\beta}=4.962 \times 10-{ }^{10} \mathrm{yr}^{-1} ;{ }^{40} \mathrm{Ar} /{ }^{36} \mathrm{Ar}$ atmosphere $=295.5$. All errors are given at the $2 \sigma$ level.

\section{São Vicente Island}

São Vicente, $227 \mathrm{~km}^{2}$ in extent, is one of the Barlovento Islands. Its outline resembles that of a rhombus with a major (E-W) diagonal of about $24 \mathrm{~km}$ and a minor (N-S) diagonal of about $16 \mathrm{~km}$. It is part of a NW-SE trending ridge rising on a $3.5-4 \mathrm{~km}$ deep oceanic floor (Dash et al., 1976) that includes also the islands of Santo Antao, Santa Luzia, Branco, Razo and São Nicolau. The depth of the sea floor between São Vicente and Santa Luzia does not reach $50 \mathrm{~m}$, whereas between São Vicente and Santo Antao it reaches $500 \mathrm{~m}$ (Fig. 1).

Three morphological zones in a roughly concentric arrangement can be distinguished. They correspond to different geological units. The zone located at the core of the island is a flat depression with some scattered low hills ( $50-150 \mathrm{~m}$ ) often covered by aeolian sands. (Figs. 2 and 3).

The central zone is rimmed by a mountain range of gently seaward dipping lava flows and scarce associated pyroclastics. The discontinuous curved range, which reach an altitude of between 300 and $700 \mathrm{~m}$, is interrupted by three main valleys that connect the flat core of the island with the sea at Mindelo Bay in the north-west, San Pedro Bay southwest, and Calhau southeast (Fig. 2).

Finally, the zone located outside the curved range, is represented by a few well preserved strombolian cones and some lava flows which has developed platforms that have taken terrain from the sea (Bahia das Gatas and Calhau-Viana volcanoes) (Fig. 2).

The volcano-stratigraphic model proposed here is compared in Table 1 with previous models for São Vicente (Bebiano, 1932; Serralheiro, 1966, 1976; Jorgensen and Holm, 2002; Holm et al., 2008). The oldest unit is the Submarine Edifice cropping out as part of a Basal Complex that also comprises a number of intrusion bodies and dikes. The most important subaerial volcanic unit is the São Vicente Edifice (SVE) within which several growing and destruction stages are distinguished. After this long-lived volcanism only very local recent activity occurred. A simplified geological map and a sketchy profile of the island are shown in Figs. 4 and 5, respectively.

\section{The Basal Complex (Submarine Edifice)}

The Basal Complex (BC) is the oldest unit on São Vicente and crops out in the central core of the island, only reaching the coast at Mindelo Bay (Fig. 4). Its geological meaning is comparable to the Basal Complex of the Canary Islands (i.e. Fúster et al., 1968; Stillman et al., 1975). As we have stated in previous papers, this Canarian unit includes not only the submarine growth stage of the island, but also the hypabyssal roots (plutonic bodies and dikes) of both the submarine and the later subaerial volcanics (Ancochea et al., 1996).

The BC of São Vicente consists of basaltic volcanic rocks and basic plutonic rocks as well as intermediate and felsic rocks, all crossed by 


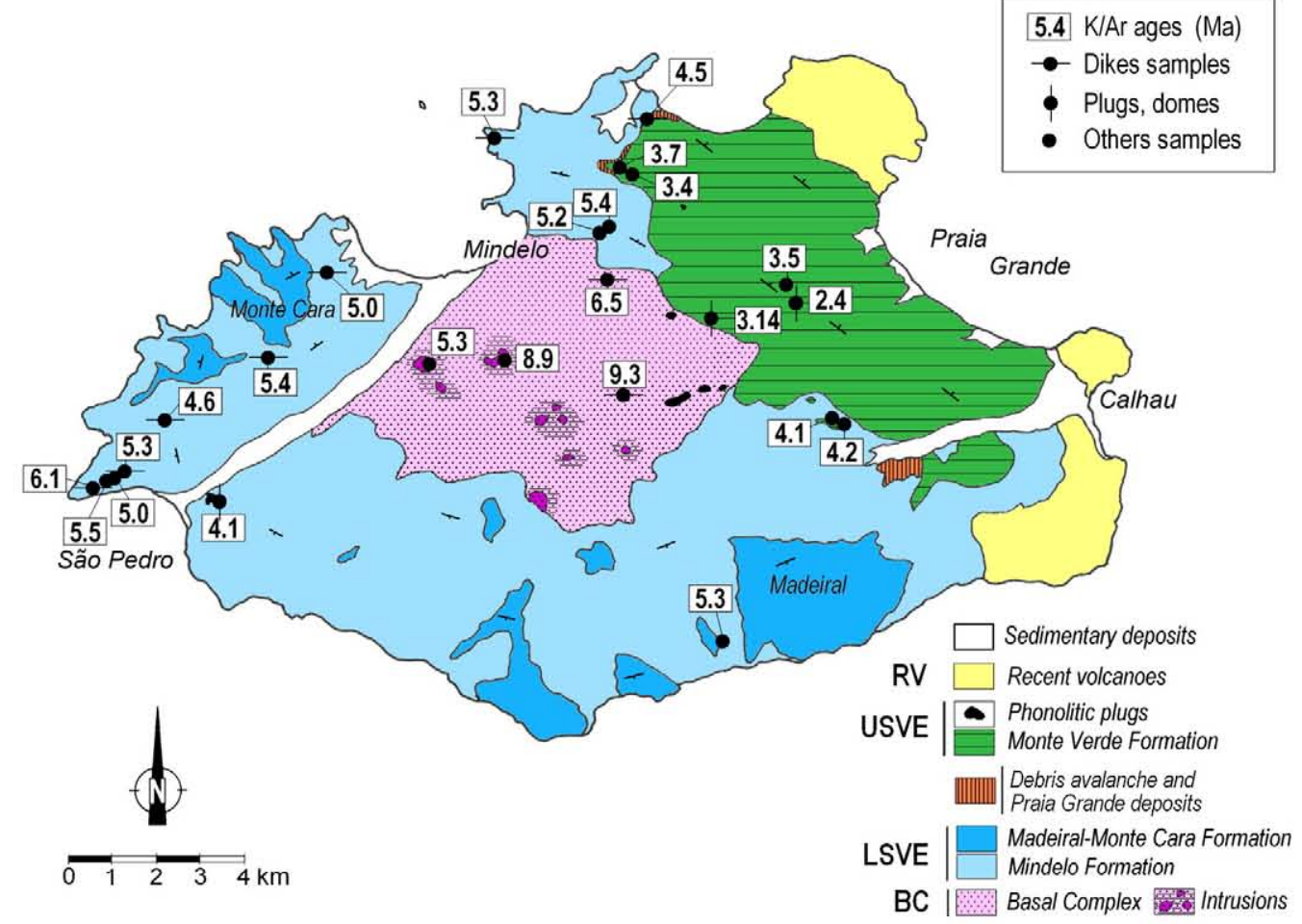

Fig. 4. Simplified geological map with the main stratigraphical units. Location and radiometric age of dated samples are shown.

an intense and complex dike swarm. In contrast to some other Basal Complexes on either Cape Verde (i.e. Maio) or the Canary Islands (i.e. Fuerteventura) marine sediments are not observed.

The bulk of the BC rock outcrops is represented by the dike swarm (normally $60 \%$ and occasionally 90 to $100 \%$ of the total volume). The dikes strike all directions, though $\mathrm{E}-\mathrm{W}$ is the most frequent: roughly $70 \%$ of them show directions comprised between $N 60^{\circ}$ and $N 130^{\circ}$, or more restrictively, nearly $40 \%$, show strikes between $N 80^{\circ}$ and $N 110^{\circ}$ (Fig. 6). The basaltic and gabbroic rocks appear as screens among the dike network.

The outcrops of basaltic rocks are most abundant in the proximities of Mindelo and in the easternmost sector of the $\mathrm{BC}$ along the road from Mindelo to Calhau. These basalts are greenish highly weathered porphyritic rocks. The olivine and pyroxene phenocrysts are transformed into secondary serpentine and chlorite. The plagioclase crystals are also highly altered, and vesicles, when present, are systematically filled by carbonate and zeolites. The dike density is so high that any original structure of the country rock cannot be recognized Contacts between lava flows are not seen. According to their composition and to their lower position (the lowest topographically and stratigraphically below the subaerial volcanic units) they can be interpreted, like on other islands, as remains of the submarine edifice of the São Vicente Island.

The plutonic rocks, mostly gabbroic, are usually observed in similar screens to those of the basaltic country rocks. Their original mineral composition is in general highly transformed by weathering. However, the dike density decreases to much lesser values of only $10 \%$ to $40 \%$ in some points, allowing the exposure of larger plutonic bodies in which compositional layering, among other structures, is frequently recorded. These gabbroic rocks are especially well observed in the central zone of the island (Figs. 3 and 4), from Monte Juliao towards the S and SW. Their contact relationships with

\section{WSW}
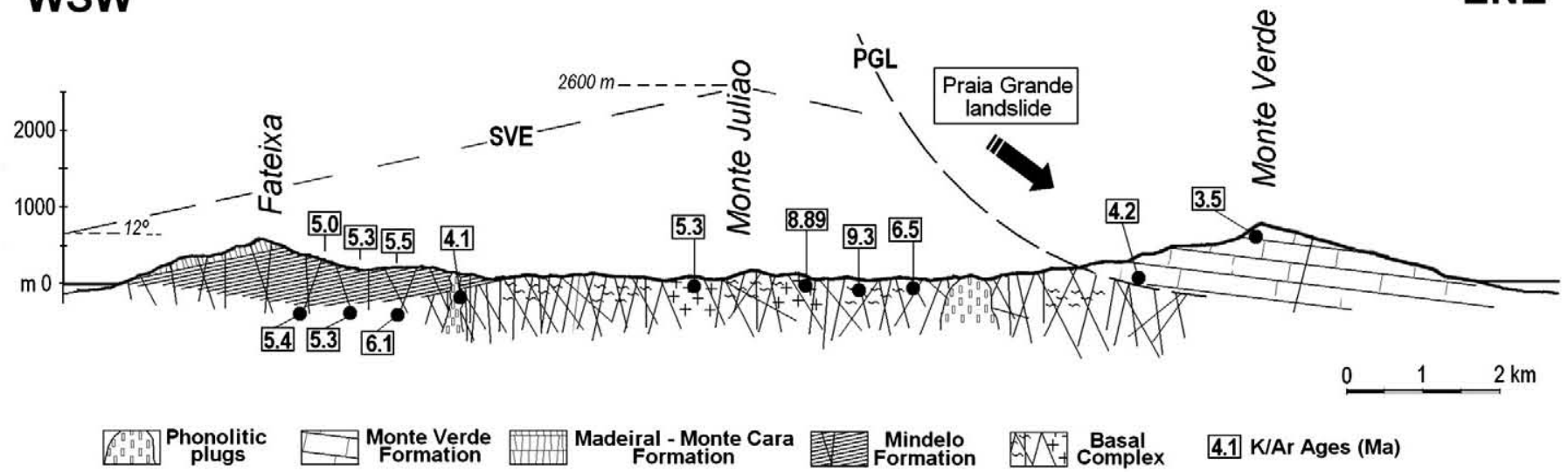
Formation

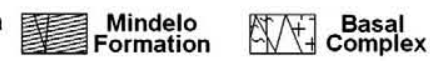

4.1 K/Ar Ages (Ma)

Fig. 5. Simplified cross-section and representative radiometric ages of the São Vicente Island. The SVE dashed line represents an approximate minimum profile reached by the São Vicente edifice on the basis of a slope of $12^{\circ}$ and a retrograde shoreline between 2 and $3 \mathrm{~km}$ implying a minimum height of $2600 \mathrm{~m}$. See discussion in text. The PGL dashed line represents the hypothetical scar of the Praia Grande landslide. 


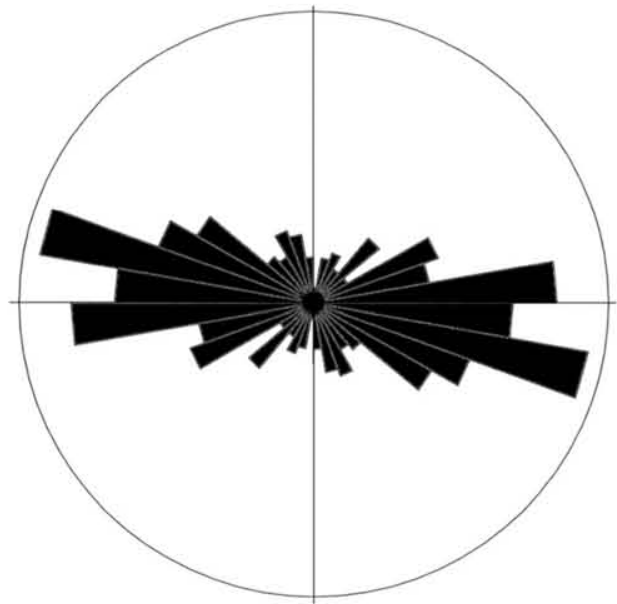

Fig. 6. Rose diagram of Basal Complex dikes strikes (259 measurements).

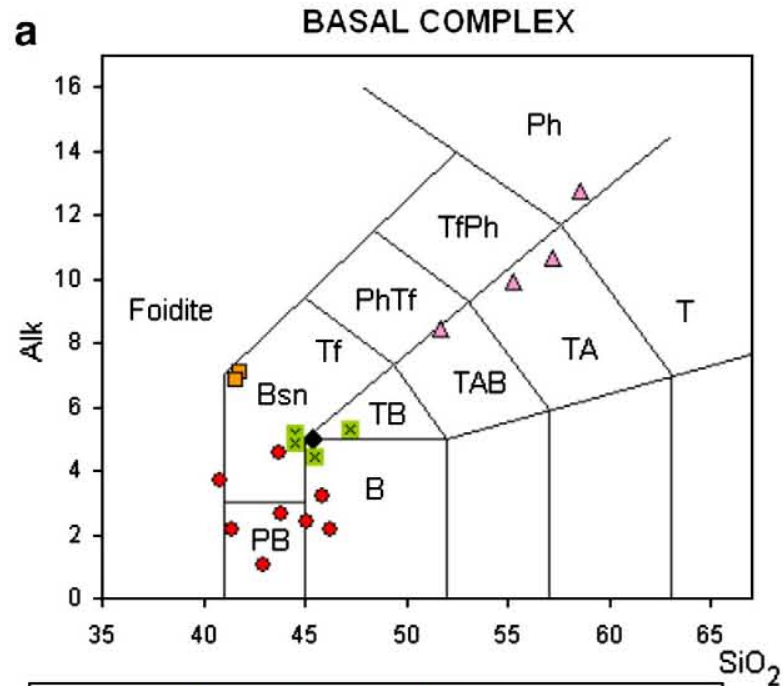

$\bullet$ BC Basalts xDikes Gabbros $\square$ Alkali gabbros $\triangle$ Syenites
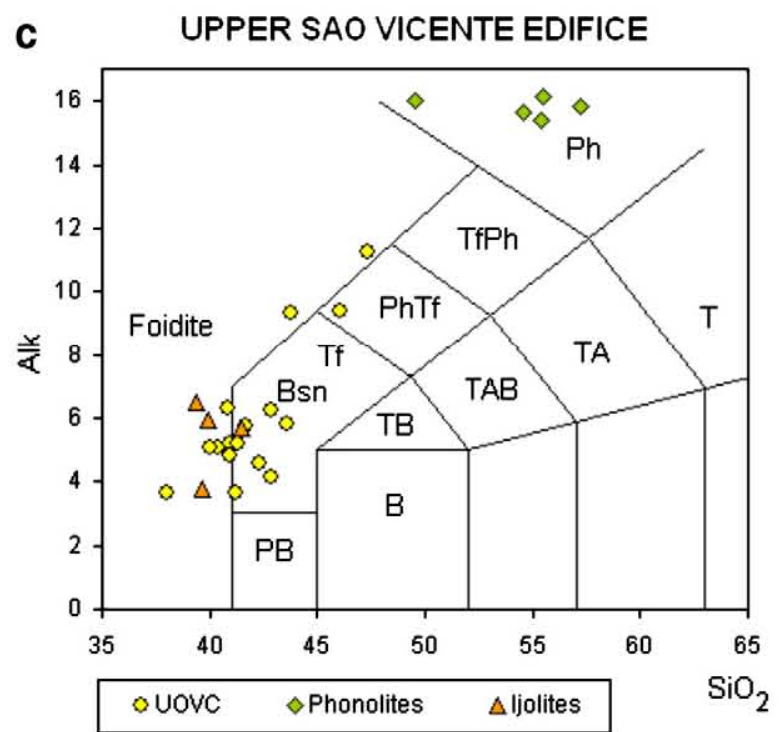

the surrounding units are masked by the dike network. At a few other locations, as for instance in the vicinity of Tope da Caixa, the gabbros reach outcrop areas of more than $1 \mathrm{H} \mathrm{m}^{2}$ in extent.

They are mostly clinopyroxene and plagioclase bearing gabbros. olivine is often absent, biotite is frequent, and amphibole is occasionally found in these rocks. In some localities, for example in some outcrops in Monte Juliao, the plutonic rocks are nepheline bearing alkali gabbros or even ijolites. No significant differences in the density of diking among these particular lithological rock types are appreciated. Less abundant are other more fractionated types, from leucogabbros to monzonites, monzosyenites and peralkaline nepheline-syenites, which also appear crosscut by dikes but in a lesser proportion, a fact that may be reflecting a somewhat younger age of these intrusions.

The $\mathrm{BC}$ dikes are mainly basic, aphanitic and greenish in colour, formed by completely transformed mineral phases, which have been modified into unrecognizable microcrystalline or criptocrystalline products. Only sparsely porphyritic olivine and pyroxene bearing basalts or even ankaramitic basalts occur, analogous in many respects b

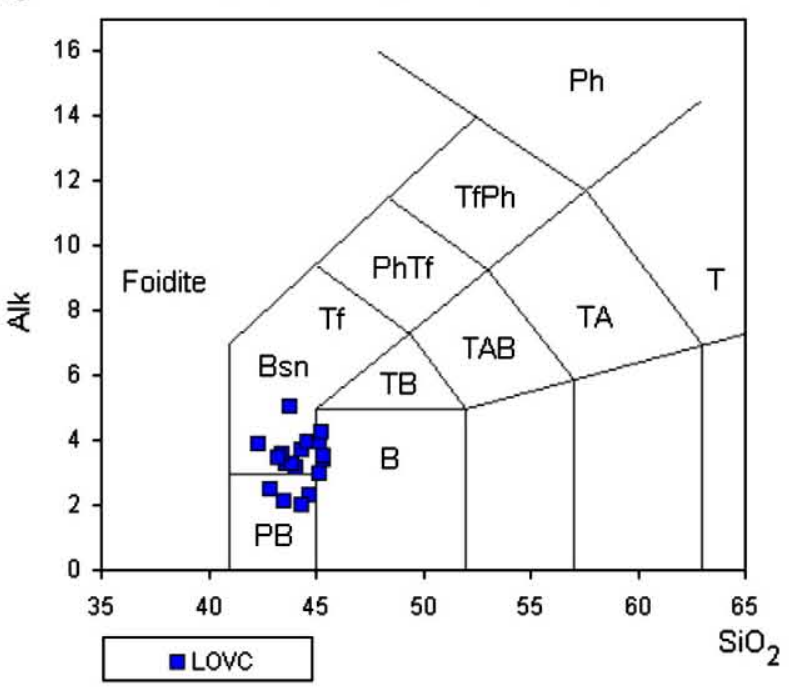

d

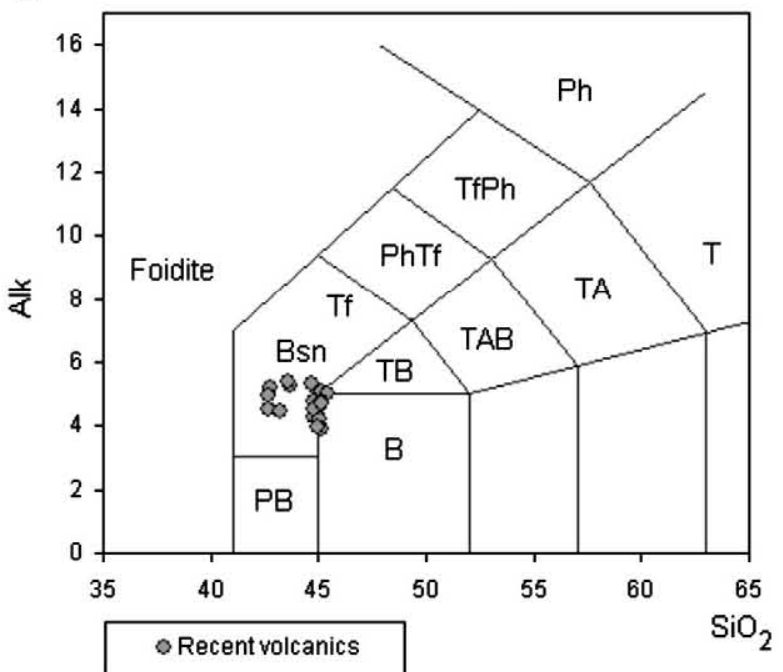

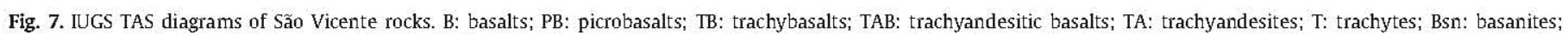

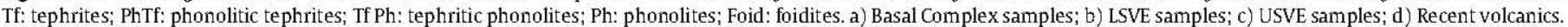


to those cross-cutting later units, which could indicate a younger age for this porphyritic set of dikes rocks.

Fig. 7a shows the analytical data of representative $\mathrm{BC}$ rock samples plotted in the total alkali-silica diagram. Due to the high degree of transformation exhibited by the $\mathrm{BC}$ basaltic rocks, only one sample was suitable for analysis. That sample plots close to the boundary separating the basalts, trachybasalts and basanites fields. A similar composition is obtained for the aphanitic dike samples. As for the gabbros they are plotted in the picrobasalts, basalts and basanites fields. The alkali gabbros plot between basanites and foidites. Finally, the felsic plutonic rocks plot not far from the line separating the alkaline and strongly alkaline fields, corresponding to trachyandesites and phonolites in the volcanic domain.

The contact relationship between the $\mathrm{BC}$ with the overlying units is seldom observed. It is sometimes covered by sand dunes as for example in the western sector. To the north, in the vicinity of Mindelo the contact seems to be gradual, although in some other zones, for example in Tope da Caixa the $\mathrm{BC}$ rocks are separated from the upper units by several meters thick breccias exhibiting basaltic, gabbroic and greenish aphanitic fragments, which no doubt originated after the destruction of the $\mathrm{BC}$.

As stated above, the lack of fossil bearing sedimentary rocks in the BC prevents to assign a biostratigraphic age to this unit. On the other hand, due to the metamorphic or metasomatic processes associated with the repeated intrusions, radiometric age data are rather difficult to be obtained (i.e. Cantagrel et al., 1984; Feraud et al., 1985; Ancochea et al., 2006). We have obtained (Table 2) two K/Ar ages of $6.5 \pm 0.2 \mathrm{Ma}$ and $9.3 \pm 0.3 \mathrm{Ma}$ from two dikes and two more ${ }^{40} \mathrm{Ar} /{ }^{39} \mathrm{Ar}$ ages of $5.3 \pm$ $0.7 \mathrm{Ma}$ and $8.9 \pm 1.6 \mathrm{Ma}$ corresponding to gabbroic rocks. Holm et al. (2008) dated by means of ${ }^{40} \mathrm{Ar} /{ }^{39} \mathrm{Ar}$, a dike cross-cutting syenites, which gave a similar age of $6.6 \pm 0.3 \mathrm{Ma}$. Some of these age data (6.6, 6.5 and $5.3 \mathrm{Ma}$ ) are similar, or only slightly older than the early phase of the São Vicente Edifice so they could be interpreted as their hypabyssal and plutonic roots. The other older ages (9.3 and 8.9 Ma) must necessarily correspond to earlier magmatic episodes. The fact that the dikes show an extremely variable degree of transformation (almost unaltered and strongly transformed dikes) altogether with the existence of plutonic rocks highly and slightly intruded by dikes, supports these assumptions. If we take into account that later thermal events might have affected these rocks, some of this group of data should be considered as minimal ages.

It has not been possible to determine the age of the $\mathrm{BC}$ alkali gabbros. Since their composition (Fig. 7a) is similar to that of the intrusions and plugs found in the USVE (Fig. 7c), these rocks might represent hypabyssal roots of the USVE stage. Nevertheless, the intense diking that affects them suggests that the alkali gabbros can rather correspond to an older magmatic phase of as yet unknown age.

\section{The São Vicente Edifice}

The most prominent and extensive unit of the island is the São Vicente Edifice (SVE), which is formed by a thick lava pile with some inter-layered pyroclastics dipping seaward. The intense erosion has left a $300-700 \mathrm{~m}$ high mountainous range as remnants surrounding the island core.

Serralheiro (1966) interpreted the edifice as a single composite volcano. More recently Jorgensen and Holm (2002) and Holm et al. (2008) separated it in two different complexes: the old Volcanic Complex and the Intermediate Volcanic Complex (Table 1). The division is based on the geochemical composition of their materials and the number of dikes, much larger in the old Volcanic Complex.

As we show further on, the SVE is a single major edifice including two different constructive stages (the Lower and the Upper Edifices) separated by an important collapse episode (the Praia Grande lateral collapse). The products of the early stage covered nearly the entire island, whereas those of the late stage were emplaced in a more restricted area filling the depression created after destruction of the early northeastern flank.

Table 2

New radiometric ages of São Vicente Island rocks.

\begin{tabular}{|c|c|c|c|c|c|c|c|c|}
\hline \multirow[t]{2}{*}{ Sample } & \multirow[t]{2}{*}{ Location } & \multirow[t]{2}{*}{ Composition } & \multicolumn{2}{|c|}{ UTM coordinates } & \multirow{2}{*}{$\begin{array}{l}{ }^{40} \mathrm{Ar}^{*} \\
\left(\mathrm{scc} / \mathrm{gr} \times 10^{-5}\right)\end{array}$} & \multirow[t]{2}{*}{$\%{ }^{40} \mathrm{Ar}^{*}$} & \multirow[t]{2}{*}{$\% \mathrm{~K}$} & \multirow{2}{*}{$\begin{array}{l}\text { Age } \\
\text { (Ma) }\end{array}$} \\
\hline & & & $\begin{array}{l}\text { Longitude } \\
\text { W }\end{array}$ & $\begin{array}{l}\text { Latitude } \\
\mathrm{N}\end{array}$ & & & & \\
\hline \multicolumn{9}{|c|}{ Basal Complex } \\
\hline V-78 & Ribeira de Juliao & Basaltic dike & 718.754 & 1.865 .790 & 0.05 & 38.9 & 1.39 & $9.3 \pm 0.3$ \\
\hline V-141 & Km 5, road Mindelo-Calhau & Dike & 715.458 & 1.864 .329 & 0.034 & 43.4 & 1.33 & $6.5 \pm 0.2$ \\
\hline \multicolumn{9}{|c|}{ Lower São Vicente Edifice } \\
\hline V-2 & Farol & Basaltic lava flow & 703.952 & 1.861 .851 & 0.023 & 52.4 & 1.06 & $5.5 \pm 0.1$ \\
\hline V-138 & Cabeza do Gato & Picrobasalt lava-flow & 718.683 & 1.859 .112 & 0.014 & 39.4 & 0.65 & $5.3 \pm 0.2$ \\
\hline V-1 & Farol & Ankaramite lava flow & 704.080 & 1.861 .697 & 0.011 & 33.0 & 0.54 & $5.0 \pm 0.3$ \\
\hline V-4 & Farol & Basaltic dike & 704.137 & 1.861 .898 & 0.021 & 68.0 & 0.89 & $6.1 \pm 0.2$ \\
\hline V-7 & Fateixa & Basaltic dike & 708.200 & 1.865 .400 & 0.017 & 38.1 & 0.78 & $5.4 \pm 0.2$ \\
\hline V-5 & Farol & Basaltic dike & 704.137 & 1.861 .928 & 0.022 & 60.5 & 1.08 & $5.3 \pm 0.1$ \\
\hline$V-53$ & Cova do Tarrafe & Basaltic dike & 707.392 & 1.864 .419 & 0.018 & 47.9 & 0.97 & $4.6 \pm 0.1$ \\
\hline V-11 & Joao Ribeiro & Oceanite sill & 712.675 & 1.870 .567 & 0.015 & 42.6 & 0.71 & $5.3 \pm 0.2$ \\
\hline V-6 & Lazareto & Basaltic sill & 709.033 & 1.866 .898 & 0.02 & 45.6 & 1.03 & $5.0 \pm 0.2$ \\
\hline$V-115$ & Road to Mte Verde & Basaltic fragment & 716.366 & 1.867 .801 & 0.026 & 67.2 & 1.21 & $5.4 \pm 0.1$ \\
\hline V-114 & Road to Mte Verde & Basaltic fragment & 716.366 & 1.867 .801 & 0.023 & 70.9 & 1.14 & $5.2 \pm 0.1$ \\
\hline \multicolumn{9}{|c|}{ Upper São Vicente Edifice } \\
\hline$V-106$ & Bairro Branco & Nephelinite lava-flow & 719.200 & 1.864 .271 & 0.024 & 52.0 & 1.43 & $4.2 \pm 0.1$ \\
\hline V-109 & Bairro Branco & Nephelinite lava-flow & 719.200 & 1.864 .271 & 0.011 & 17.7 & 0.67 & $4.1 \pm 0.4$ \\
\hline$V-20$ & Joao Evora & Nephelinite lava-flow & 715.818 & 1.869 .657 & 0.006 & 32.9 & 0.42 & $3.7 \pm 0.1$ \\
\hline V-29 & Monte Verde & Basanite lava-flow & 719.647 & 1.867 .368 & 0.021 & 59.3 & 1.5 & $3.5 \pm 0.09$ \\
\hline$V-21$ & Joao Evora & Nephelinite lava-flow & 715.904 & 1.869 .319 & 0.01 & 22.3 & 0.7 & $3.4 \pm 0.3$ \\
\hline V-98 & Mato Inglés & Nephelinite plug & 713.378 & 1.863 .293 & 0.013 & 43.9 & 1.1 & $3.14 \pm 0.11$ \\
\hline V-112 & Joao Evora & Ankaramite dike & 714.730 & 1.870 .340 & 0.022 & 53.2 & 1.28 & $4.5 \pm 0.1$ \\
\hline$V-52$ & Monte Pasarinho & Phonolite plug & 706.683 & 1.861 .464 & 0.069 & 64.4 & 4.3 & $4.1 \pm 0.1$ \\
\hline V-119 & Mato Inglés & Phonolite plug & 719.381 & 1.865 .577 & 0.019 & 49.1 & 1.97 & $2.4 \pm 0.06$ \\
\hline
\end{tabular}




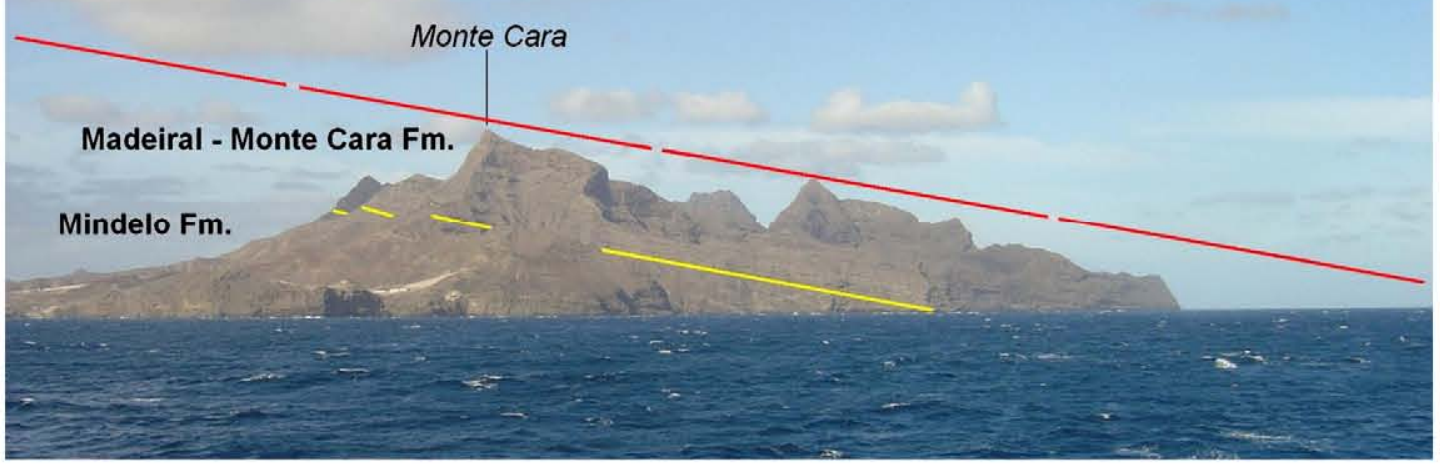

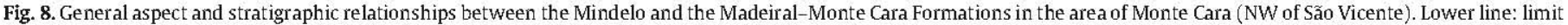

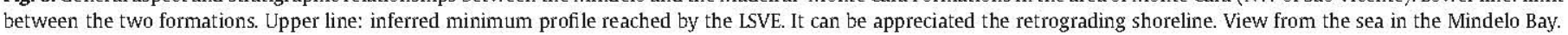

\subsection{The Lower São Vicente Edifice}

The Lower São Vicente Edifice (LSVE) spreads out all over the island. The constantly seawards dip of the remaining volcanics and the radial pattern of their cross-cutting dikes allow us to infer the development of an edifice whose main emission centre was localized in the present interior of the island.

Two successive phases can be distinguished in the LSVE (Table 1 and Fig. 4), the lower or Mindelo Formation and the upper or Madeiral-Monte Cara Formation:

The Mindelo Formation has an approximate thickness of $400 \mathrm{~m}$, and is constituted essentially of basaltic and frequently ankaramitic pahoehoe flows, with some inter-layered breccias levels. The most representative exposures are seen in the vicinity of the port in Mindelo, and in the high cliffs of Joao Ribeiro and Joao Evora in the North of the island (Fig. 2). It is also largely exposed in the western area (Lazareto Formation of Huertas et al., 2006) and in some small and round grey hills covered partially by colluvium and brownish orange coloured crusts in the southwest. In the interior of the island this formation appears at altitudes comprised between $20-30 \mathrm{~m}$ and $200-300 \mathrm{~m}$. The presence of some small volume monomictic breccias in the sequence, including pahoehoe lava fragments, suggests the existence of local destructive events already during the early growth stage of this edifice. The Mindelo Formation is crosscut by a dike and sill network of high density, which gives a characteristic appearance of layering (Figs. 8 and 9).

The Madeiral-Monte Cara Formation occupies all the high range summits N, S and W on the island (Figs. 8 and 9). Two of the most outstanding mountain peaks of the island, Monte Madeiral and Monte Cara, give the name to this formation. Well defined contact surface with the underlying Mindelo Formation cannot be seen, but the upper sequence is characterized by the strongly inclined topographic profile. This sequence is about $600-700 \mathrm{~m}$ and consists of aa basaltic lava flows and some pyroclastic levels. The lava flows exhibit well developed scoria horizons alternating with the massive parts of the flows. As for the basaltic pyroclastics, some buried strombolian cones are observed particularly in the SE. The unit is also traversed by abundant subvertical dikes but sills are very scarce. The average dip of the lava flows is about $10^{\circ}-12^{\circ}$ seawards.

The LSVE lava flows as a whole are essentially basaltic. Ankaramites, as well as ankaramitic, picritic and pyroxene-olivine bearing basalts are rather abundant. Plagioclase bearing basalts are locally frequent only. In the Madeiral-Monte Cara Formation trachybasalts are also present. The associated dikes show similar compositions though they are dominantly aphanitic. Representative chemical analysis of LSVE lava flows and dikes are displayed in Fig. 7b; they all have homogeneous compositions of

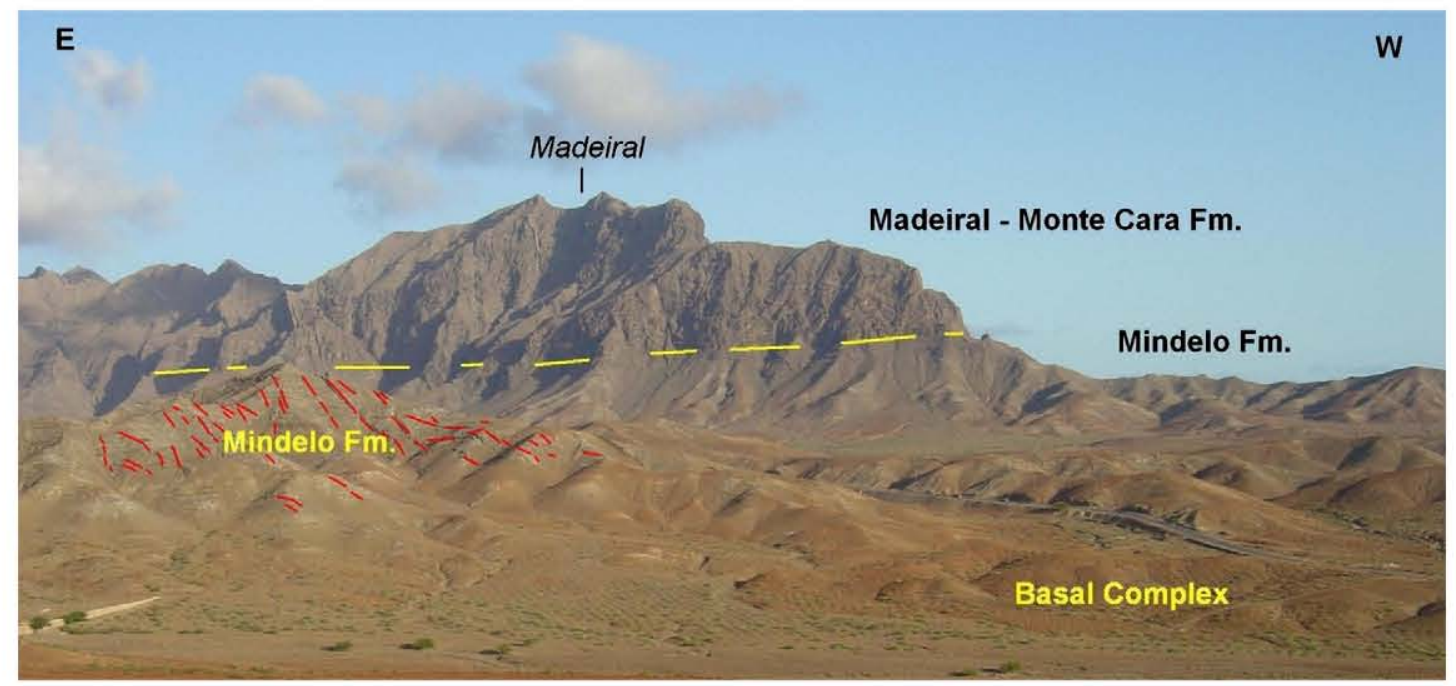

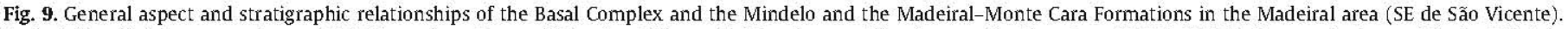

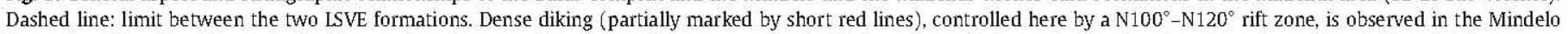
Formation. View from Morro do Cavalo area. (For interpretation of the references to color in this figure legend, the reader is referred to the web version of this article.) 
alkali basalts, basanites and picrites, plotted in the same field as the Basal Complex gabbros (Fig. 7a).

Holm et al. (2008) dated by ${ }^{40} \mathrm{Ar} /{ }^{39} \mathrm{Ar}$ a single LSVE rock sample from the southwestern sector at $5.92 \pm 0.04 \mathrm{Ma}$. By means of $\mathrm{K} / \mathrm{Ar}$ method we have dated several samples from different sectors of the LSVE (Table 2, Figs. 4 and 5). Three of them are dated at 5.5, 5.3 and 5.0 Ma correspond to lava flows, and six other at $6.1,5.4,5.3,5.3,5.0$ and $4.6 \mathrm{Ma}$ to cross-cutting dikes. Two more ages of 5.4 and $5.2 \mathrm{Ma}$ were obtained from fragments collected from breccias levels. All these consistent ages, including that of Holm et al. (2008), indicate a period of activity from at least 6.1 to $4.6 \mathrm{Ma}$. The ages obtained from lava flows ( 5.9 to $5.0 \mathrm{Ma}$ ) belong to the Mindelo Formation and the base of the Madeiral-Monte Cara Formation because the middle and high parts of that unit are inaccessible for sampling. The most recent age from the dike of $4.6 \mathrm{Ma}$ may fairly represent also that of the not sampled levels.

\subsection{The basaltic dike swarms}

The LSVE is characterized by the large amount of cross-cutting basic dikes which, as stated above, have the same age as the lava flows. A first group of dikes is vertical or nearly vertical whereas a second group is slightly inclined seawards as the lava flows. Unlike the vertical dikes, which traverse both the lower and the upper formations, the slightly inclined dikes appear essentially in the Mindelo Formation decreasing in number upwards until disappearing in the Madeiral-Monte Cara Formation.

The inclined dikes, which generally have a thickness of less than $1 \mathrm{~m}$, are extraordinarily abundant (one every $2-5 \mathrm{~m}$ ) in the lowermost levels of the Mindelo Formation (Fig. 10). Their dip is always lower than $35^{\circ}$, often less than $10^{\circ}$ where the dikes pass locally into sills where they became concordant with the pahoehoe lava flows. As these sills are systematically cross-cut by vertical or nearly vertical dikes the former must be older.

The vertical dikes cross-cutting the Mindelo and Madeiral-Monte Cara formations are much more abundant than the older sills. These typically basaltic dikes have a thickness comprised between a few centimetres and $5 \mathrm{~m}$, although $65 \%$ of them are between $30 \mathrm{~cm}$ and $1 \mathrm{~m}$ thick with an average thickness of $70 \mathrm{~cm}$ (standard deviation 0.6).

A total amount of 584 strike measurements in 51 different stations have been obtained from dikes cross-cutting the LSVE. From their general distribution a simple radial pattern with a centre near the core of the island is inferred. Fig. 11 shows rose diagrams for the total number of dike strikes. The differences appreciated in the number of dikes in the

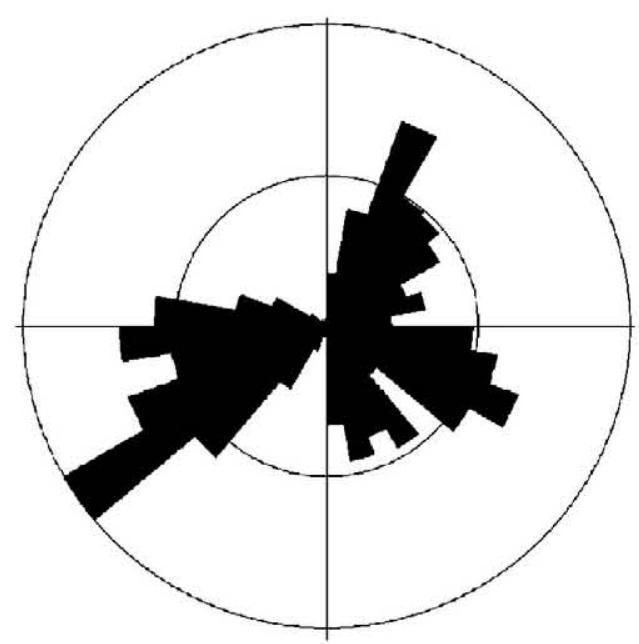

Fig. 11. Lower São Vicente Edifice dikes: rose diagrams based on 584 strike measurements. Circles correspond to 5 and $10 \%$, respectively.

different sectors are to a certain extent due to the unequal distribution of the stations. This is the case of the main absence of measurements in the area of Mindelo Bay where the LSVE is not exposed (Fig. 4). However in some other sectors, as for example in the SW, the number of dikes is clearly smaller, only one every $50-100 \mathrm{~m}$, in contrast to the normal average of one dike every $5-10 \mathrm{~m}$. On the other hand some of the directions most frequently measured $\left(\mathrm{N} 20^{\circ}-30^{\circ} ; \mathrm{N} 90^{\circ}-120^{\circ}\right.$ and $\mathrm{N} 230^{\circ}-270^{\circ}$ ) may represent true main trends of dike intrusion defining a common triple-armed rift superimposed onto a more poorly defined radial pattern.

In many of the stations (Fig. 12), dike bundles with a maximum variation of $40-50^{\circ}$ or bimodal dike distributions that could reflect the existence of more than one single radial structure can be observed. The common bimodal distribution of dikes is evidently observed in the field (Fig. 13) and besides of every pair of trends obtained in any of the stations, the one converging toward a point located farther north in the centre of the island is systematically older.

In order to locate the approximate position of the radial swarm centre we have used our method of maximum intersections (Brändle et al., 1991), reported and applied in previous papers dealing with the reconstruction of old edifices on Fuerteventura (Ancochea et al., 1996) and La Gomera (Ancochea et al., 2003, 2008) islands.

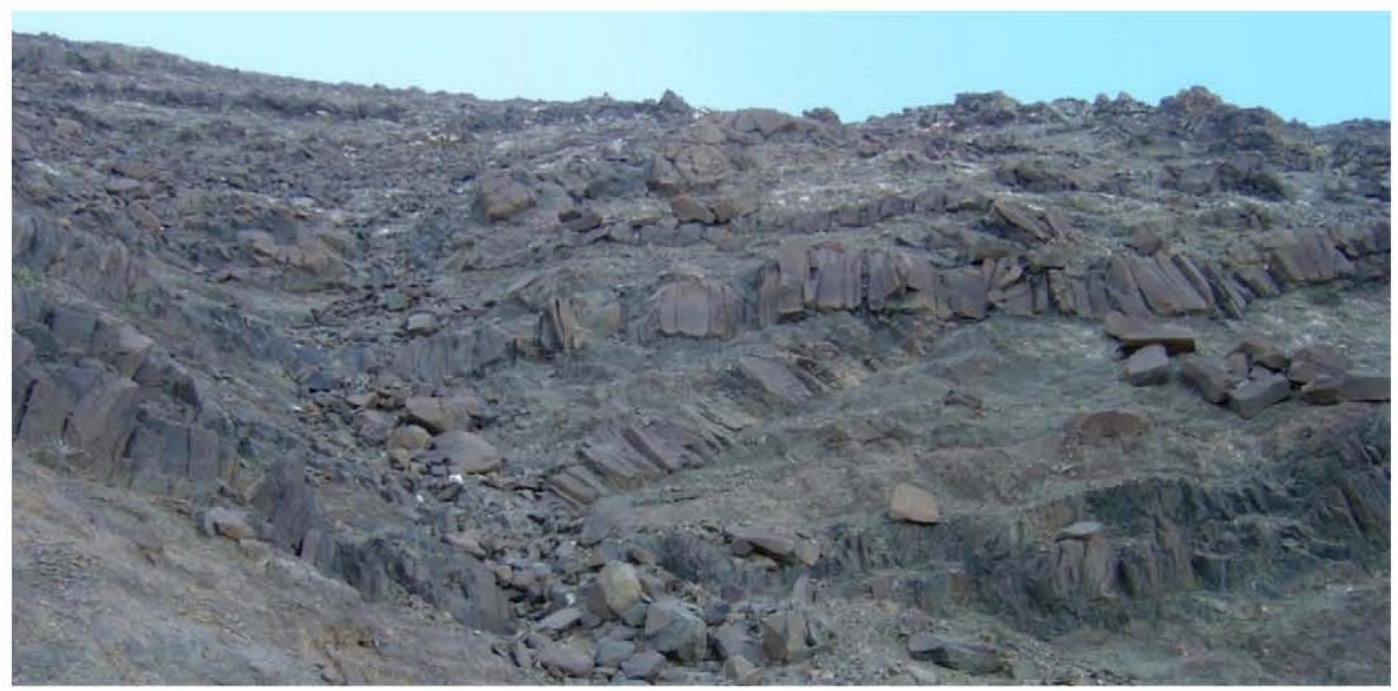

Fig. 10. Pahoehoe lava flows of the Mindelo Formation intensely crosscut by sills. Eastern lower flank of Monte Cara. Dikes and sills thickness between 1 and $2 \mathrm{~m}$. 


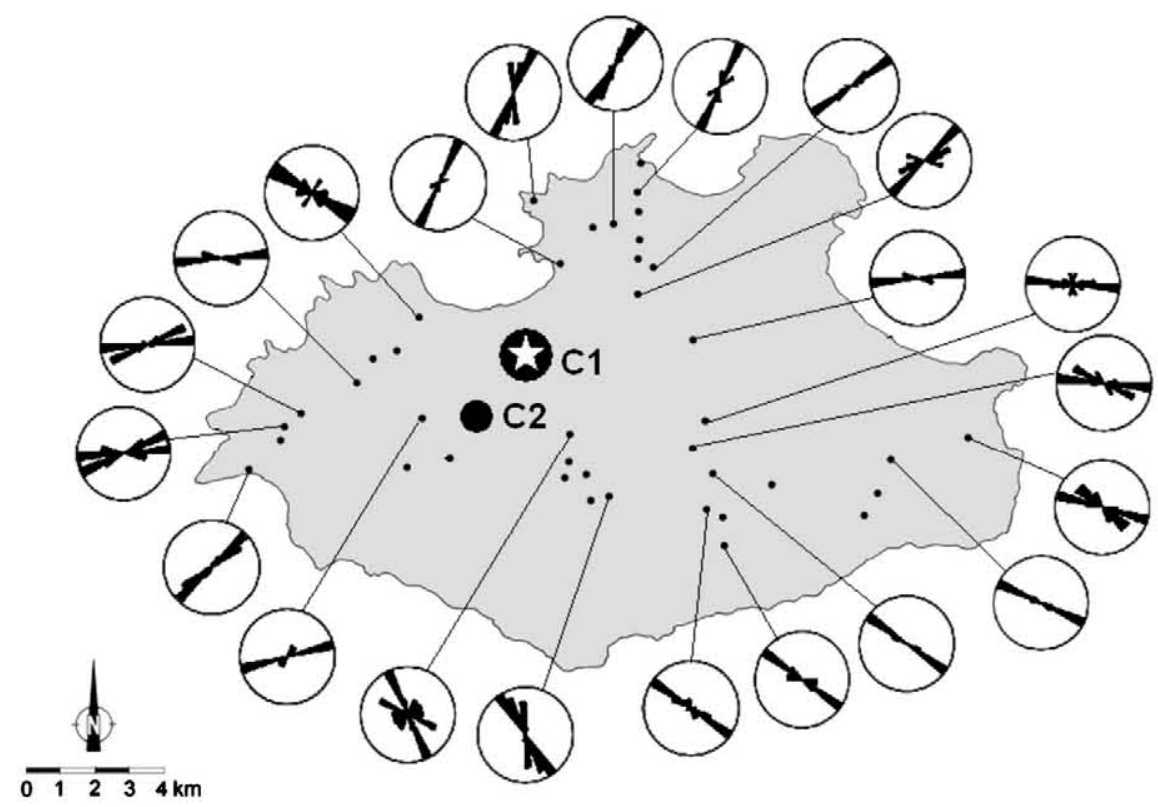

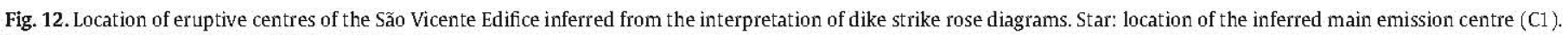
Black dot: possible further emission centre (C2).

The main centre inferred (C1, Fig. 14) (area in which the convergence of dikes is maximum) lays some $2 \mathrm{~km} \mathrm{~S}$ of Mindelo Bay, in the area of Monte Juliao, one of the zones in which gabbroic intrusions are the most abundant within the whole Basal Complex (Fig. 4). A later and less important centre (C2, Fig. 14) is located $2.5 \mathrm{~km}$ SSW of the C1 centre. The volcanic activity in the LSVE therefore would have drifted slightly south-southwards throughout the time.

\subsubsection{Morphological reconstruction of the LSVE}

All these data allow us to infer some features of the original Lower São Vicente Edifice. During the first phase of its growth (Mindelo Formation) the LSVE must have behaved as a shield volcano, a hypothesis supported by the abundance of pahoehoe lavas and the absence of pyroclastics. In the second phase (Madeiral-Monte Cara Formation), the eruptions became more explosive giving rise to abundant thicker and more viscous aa lavas as well as to pyroclastics. In addition, the higher dip developed by the lava flows and pyroclastics could suggest that the topographic profile acquired by the edifice over this second phase might have approached to that of a composite volcano. The centre of the LSVE must have been situated on land, inside the present island, about $2 \mathrm{~km} \mathrm{~S}$ of Mindelo Bay.

If the average dip of the lava flows is taken into account and the highest zones of these sequences are ideally extended seaward (Fig. 8), it is possible to state that the original area occupied by the LSVE was rather more extensive than the present island. The shoreline must have situated out at sea between 1 and $2 \mathrm{~km}$ from the present

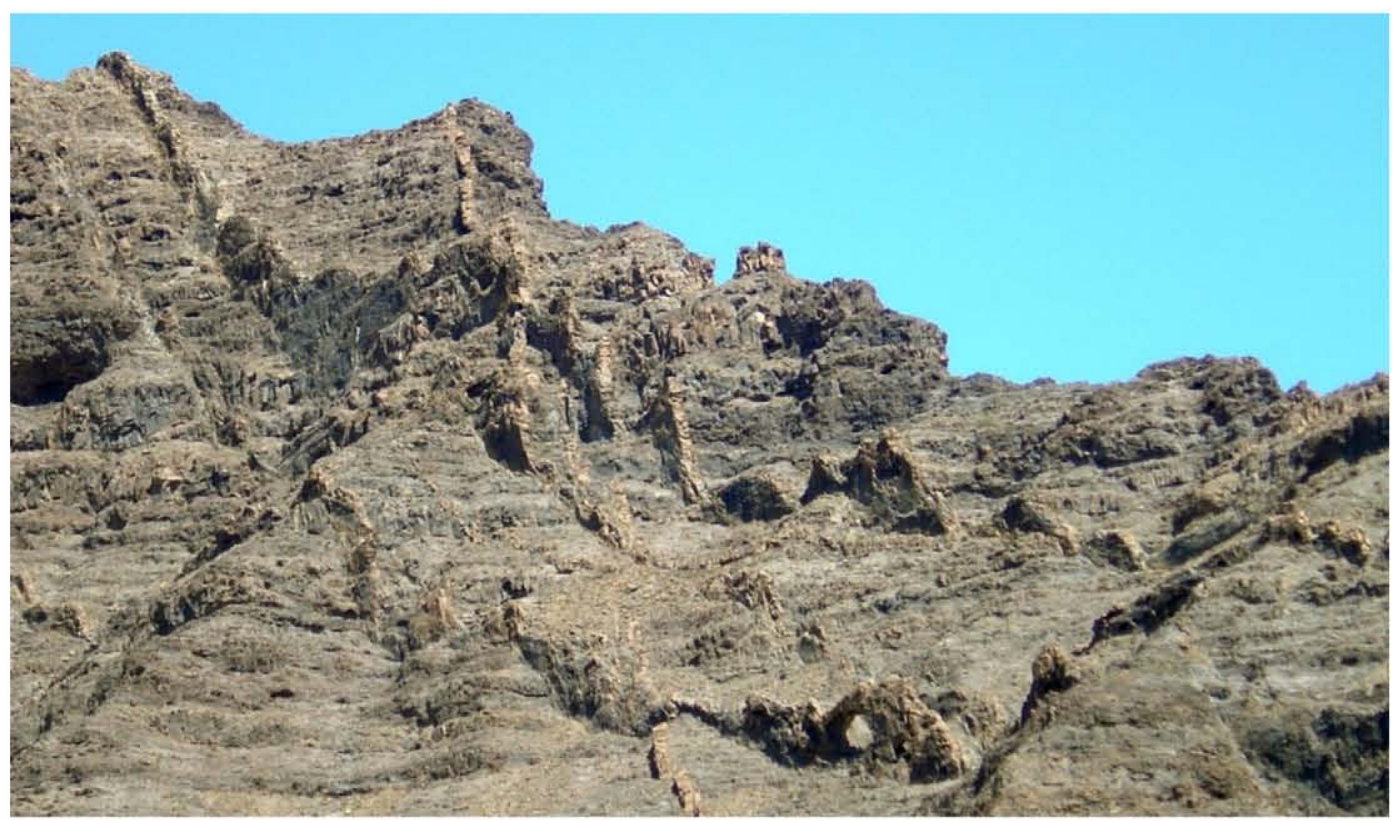

Fig. 13. Two dike systems with $20^{\circ}$ intersection angle in the upper lava flow levels of the Mindelo Formation. Western sector (area of Fateixa). Wall height about $200 \mathrm{~m}$. 


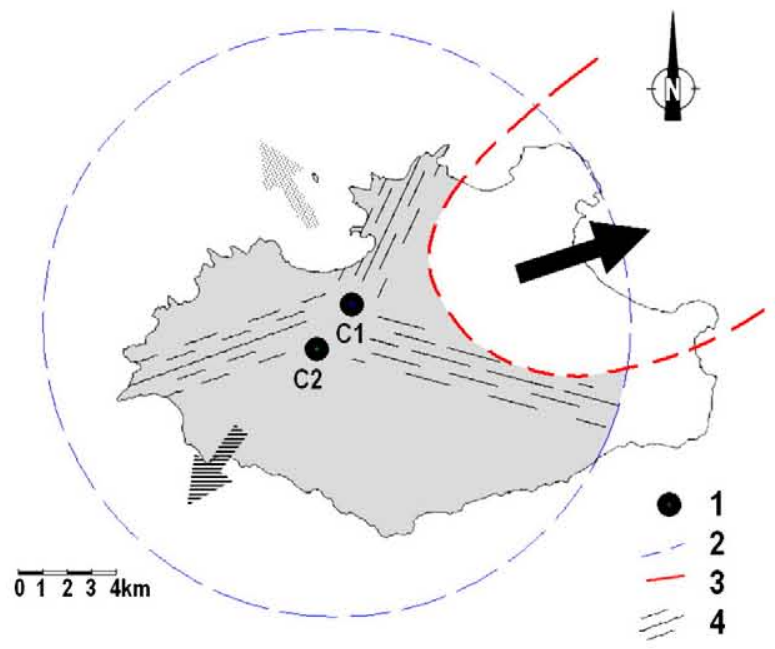

Fig. 14. Sketch of the inferred São Vicente Edifice and the Praia Grande landslide 1: LSVE emission centre: $\mathrm{C} 1$ : main emission centre; $\mathrm{C} 2$ : a second more hypothetical centre; 2: Hypothetical area occupied by the Lower São Vicente Edifice; 3: Praia Grande landslide outer edge; 4: Rift systems: Black arrow: Praia Grande landslide; Striped arrow: hypothetical São Pedro landslide; Dotted arrow: hypothetical Mindelo landslide. See text for explanation.

shoreline, an idea also supported by the remaining high cliffs that rim most of the island. From the inferred position of the centre and the shoreline it is possible to suppose that the LSVE reached a radius of some 10 to $12 \mathrm{~km}$.

As for the height reached by the volcano, given the radius and considering the dip of the lava flows (from 10 to $12^{\circ}$ ), a total height comprised between at least 1700 and $2600 \mathrm{~m}$ could be calculated. In case of an edifice with more inclined slopes analogous to those of some recent volcanoes of Cape Verde, as Fogo, which has an average slope of $15^{\circ}$, the height would have likely arrived to $3200 \mathrm{~m}$. Taking into account that, at composite volcanoes, lava flows dips increase gradually towards the summit, the last height estimated seems to be reasonable.

Since a cone $12 \mathrm{~km}$ in radius and $2500 \mathrm{~m}$ in height represents a volume of $377 \mathrm{~km}^{3}$, it can be concluded that the entire volume of the primitive LSVE could have been comprised between 300 and $400 \mathrm{~km}^{3}$.
As the volume of the present remaining edifice can be estimated in as much some $40 \mathrm{~km}^{3}$, almost $90 \%$ of the whole would have disappeared.

\subsection{The Praia Grande lateral collapse}

A giant flank collapse took place in the LSVE that modified dramatically the volcanological evolution of São Vicente. We have named the event as the Praia Grande lateral collapse because it affected mainly the sector where the present big inlet of Praia Grande Bay is located. The flank collapse destroyed almost a quarter of the LSVE, approximately the sector, which extends between $\mathrm{N} 20^{\circ}$ and $\mathrm{N} 110^{\circ}$ of the existent circular edifice (Fig. 14).

The distribution of the materials that refilled the depression gives some information about the importance of the event. We have found thick breccias in both the lateral extremes of the palaeo-depression (Fig. 15). The breccias level is several tens of meters thick, containing fragments of variable size including angular boulders, up to about $2 \mathrm{~m}$, embedded in a compact fine-grained groundmass that can be interpreted as debris avalanche deposits associated to the collapse. The petrographic types observed in both the large and the groundmass size fragments are analogous to those present in the $\mathrm{BC}$ and the LSVE rocks. At sea level, in the NE extreme of the depression, the breccias are covered by more than $40 \mathrm{~m}$ thick infilling sediments (Praia Grande deposits, Figs. 4 and 16).

The depression created was then filled up by the later Upper São Vicente Edifice emissions, which constitute at present the most prominent mountain tops on the eastern side of the island (Monte Verde, $750 \mathrm{~m}$ ).

The fact that the entire pile of materials that refilled the depression form present cliffs about $250-300 \mathrm{~m}$ in height, and also that the debris avalanche deposits are exposed at sea level may suggest that the flank collapse had a submarine extent. The dip of the infilling lava flows in this sequence allows us to suppose that they could extend at least between 2 and $3 \mathrm{~km}$ out at sea from the present shoreline.

The depression left by this flank failure was some $12 \mathrm{~km}$ wide (distance between the two outcropping breccias). The estimation of its length is more difficult to be made. The USVE materials refilling the hollow are found about $7 \mathrm{~km}$ on land from the present shoreline, which only represents a minimum value. It must also be taken into account the $2-3 \mathrm{~km}$ recession undergone by the present shoreline plus the distance from the innermost USVE present outcrops to the now disappeared landslide headwall, which make up a total amount

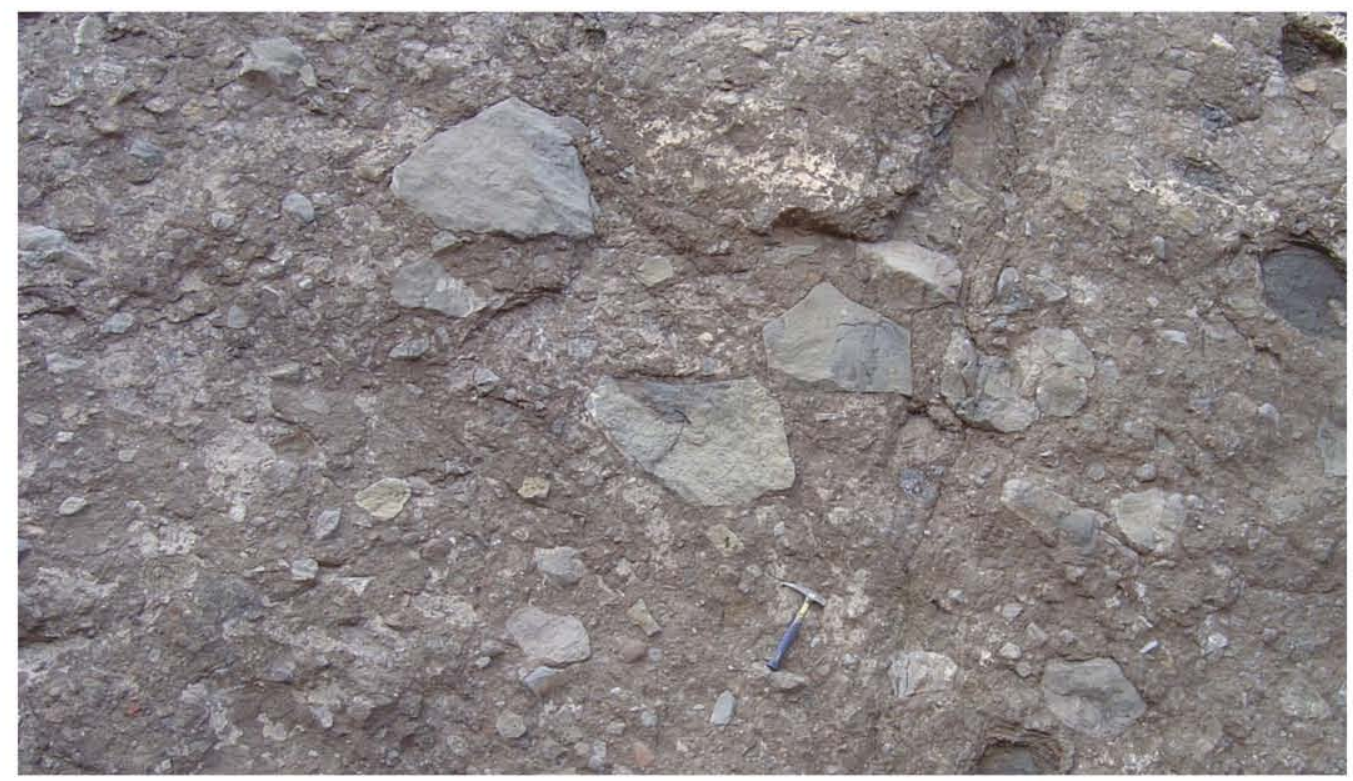

Fig. 15. A general aspect of the debris avalanche deposits in the Ribeira do Calhau Valley. 


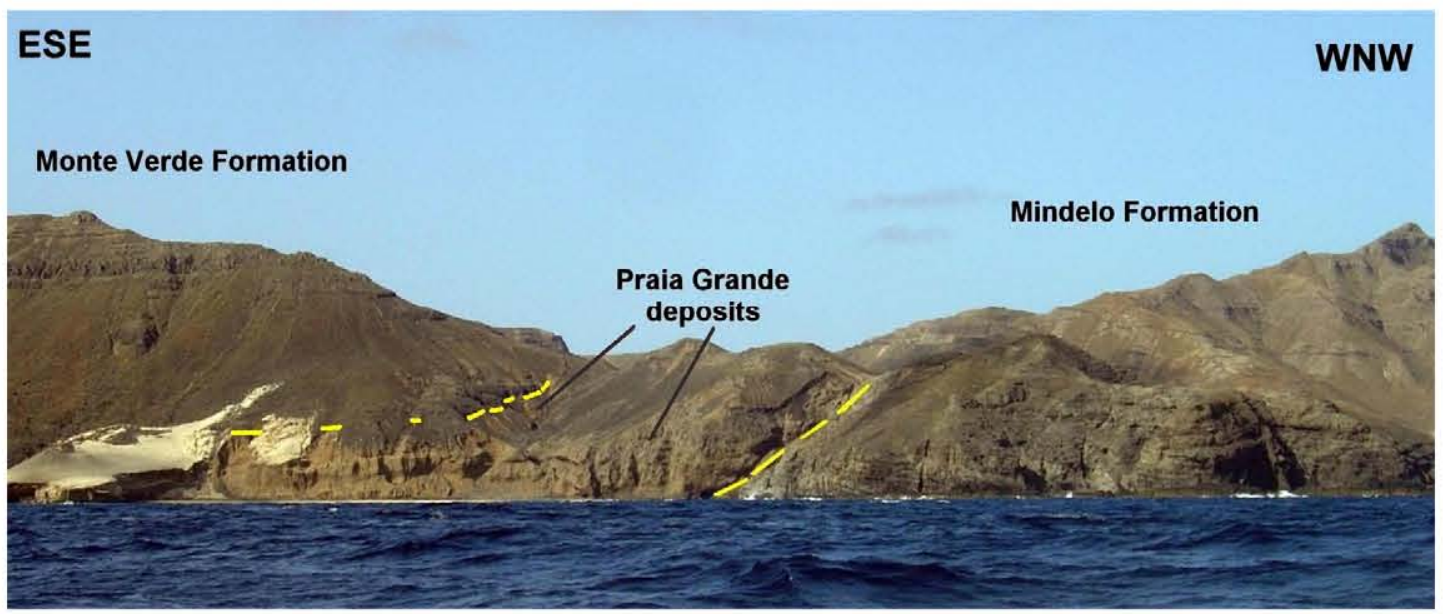

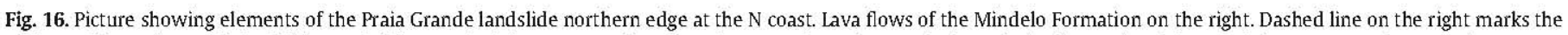

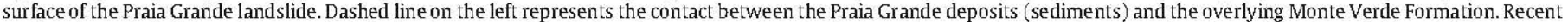
aeolian deposits in light colours on the left. (For interpretation of the references to colour in this figure legend, the reader is referred to the web version of this article.)

of $10-11 \mathrm{~km}$ (Fig. 14). According to these dimensions the landslide headwall must not have affected the summit of the LSVE.

The landslide has dragged the entire Madeiral-Monte Cara Formation in this sector since the debris avalanche deposits associated with collapse overlie the Mindelo Formation. In the innermost zones even the Mindelo Formation was also dragged because the USVE lava flows rest directly upon $\mathrm{BC}$ rocks. In the northern rim of the palaeodepression, at the coast, the bottom of these deposits are always found at sea level, whereas $2 \mathrm{~km}$ inland they appears at an altitude of $160 \mathrm{~m}$; this means a slope of some $4.5^{\circ}$. The total volume of subaerial materials displaced in the slide would be of about $90 \mathrm{~km}^{3}$, which represent a $23-30 \%$ of the entire volume of the LSVE. These figures are in the same rank as other large landslides occurred in oceanic volcanoes (Holcomb and Searle, 1991) and even as other lateral collapses described in the Canary Islands (Krastel et al., 2001; Masson et al., 2002).

\subsection{The Upper São Vicente Edifice}

The volcanic emissions in the SVE after the collapse, the Upper São Vicente Edifice (USVE) concentrated in the depression originated by the landslide. Except for some phonolitic necks and dikes or a few ijolitic bodies, no other volcanic rocks associated with the new activity are found outside the depression.
The landslide depression was filled up by volcanic materials dipping monotonously seaward (Monte Verde Formation). The general morphological aspect of the unit is also very different to that of the LSVE: irregular topped relief in the LSVE and almost flat relief in the USVE (Fig. 17).

The total thickness of the Monte Verde Formation is at least $600 \mathrm{~m}$. The lower section is especially well exposed in this central zone where it is represented by $200 \mathrm{~m}$ of thick pyroxene bearing nephelinites. Some vents and conduits of the nephelinitic rocks are also found in this particular area, a fact that complicates the reconstruction of the stratigraphic sequence.

The middle section, about $150-200 \mathrm{~m}$ in thickness, crops out widely in the Monte Verde abrupt scarp, but also constitutes most of the relief extended toward the sea that characterize the USVE. These lava flows are mostly nephelinites of several meters thickness though sometimes, near the top of this section, they occur as thinner, partly scoriaceous flows alternating with pyroclastics. They dip $4^{\circ}-5^{\circ}$ toward the sea giving a characteristic structural cuesta like relief in the southernmost outcrop area (Fig. 17).

The upper section of the formation crops out in Monte Verde itself between $550 \mathrm{~m}$ and $750 \mathrm{~m}$ at the very top (Fig. 18). These lava flows are also nephelinites, occasionally incorporating ultramafic inclusions that alternate with pyroclastics. Two breccias levels are intercalated in this section. The lower is thicker (about $15 \mathrm{~m}$ ) than the upper one,

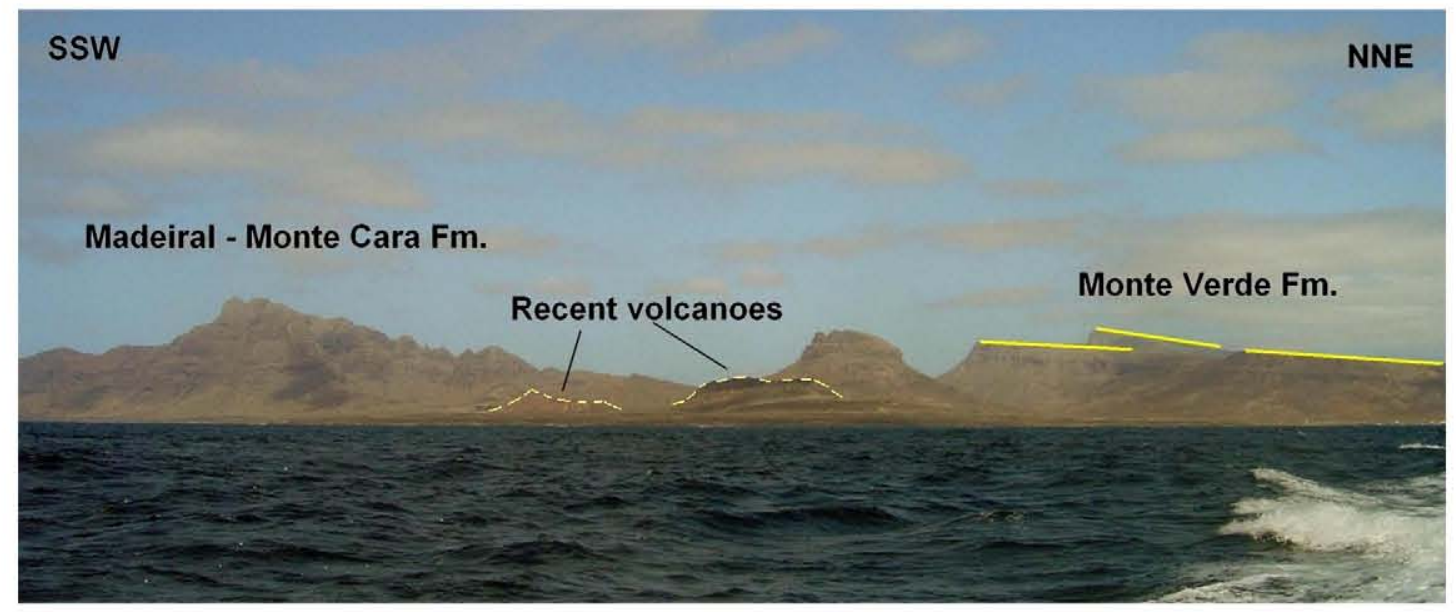

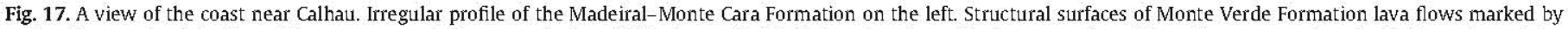

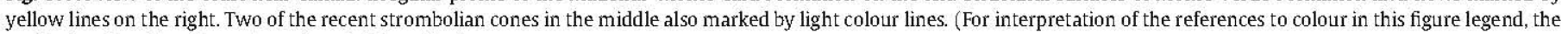
reader is referred to the web version of this article.) 


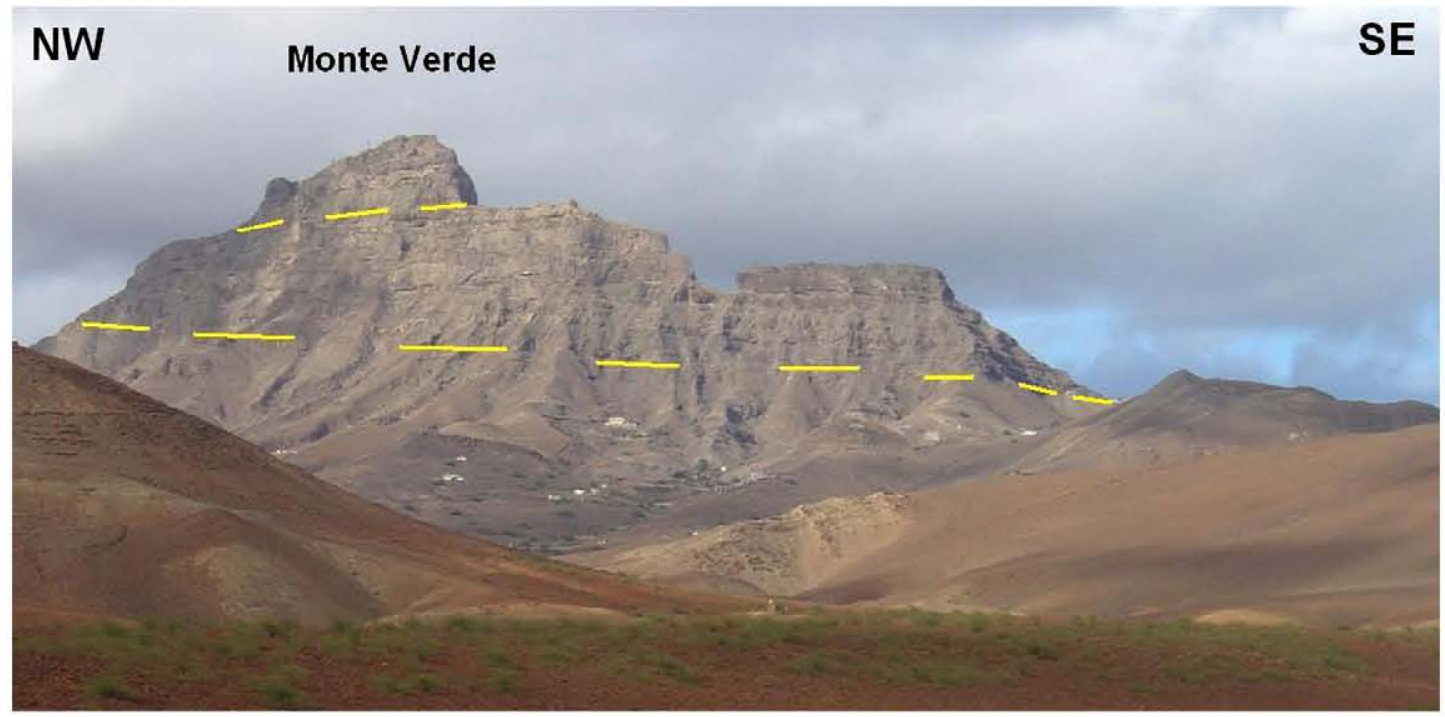

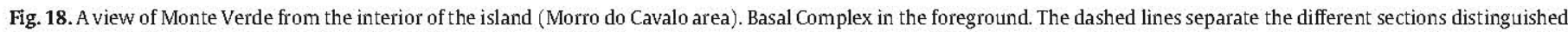
in the Monte Verde Formation.

which is only $4 \mathrm{~m}$ thick. Both the breccias levels are well consolidated and contain up to $80 \mathrm{~cm}$ large fragments of a variety of rocks: basalts, phonolites and pyroxenites suspended in a groundmass of similar composition, which also includes isolated pyroxene crystals.

As indicated above the USVE is characterized by the almost total absence of dikes. We have only found a dozen of dikes of variable strikes, most comprised between $\mathrm{N} 80^{\circ}$ and $\mathrm{N} 110^{\circ}$.

The rocks from the Monte Verde Formation are almost exclusively olivine nephelinites and pyroxene nephelinites showing frequently picritic tendencies, and some occasional basanites and melilitites. Apart from olivine, clinopyroxene and nepheline (and plagioclase in the basanites) other mineral phases: biotite, amphibole and melilite appear in minor proportions. The rock samples selected plot in the foidites and basanites fields of the TAS diagram, clearly separated from the LSVE rock samples (Fig. 7c).

Jorgensen and Holm (2002) dated by means of ${ }^{40} \mathrm{Ar} /{ }^{39} \mathrm{Ar}$ two samples from the USVE obtaining $4.73 \pm 0.09 \mathrm{Ma}$ and $4.53 \pm 0.08 \mathrm{Ma}$. Our new age data correspond to a dike cross-cutting the landslide breccias $(4.5 \pm 0.1 \mathrm{Ma})$, two nephelinite lava flows from the Monte Verde lower section $(4.2 \pm 0.1$ and $4.1 \pm 0.4 \mathrm{M})$, three more nephelinite flows from the northern sector and the Monte Verde upper section $(3.7 \pm 0.1,3.5 \pm 0.09$ and $3.4 \pm 0.3 \mathrm{Ma})$, and finally a nephelinite plug ( $3.14 \pm 0.11 \mathrm{Ma}$ ) (see Table 2 and Fig. 4).

Some plugs or small intrusions of intermediate and felsic compositions are observed cross-cutting this formation. They can also be distinguished in the older LSVE or even the BC (Figs. 4 and 5) where the largest and most significant of them, the Morro do Cavalo plug, is found.

The rocks are phonolites, tephritic phonolites and phonolitic tephrites (Fig. 7c) in which nepheline is always present with occasional haüyne. Their compositional similarity, the lack of cross-cutting dikes, and the absence of phonolitic fragments in the debris avalanche deposits associated with the landslide, which by contrast are common in the breccias intercalated in the Monte Verde sequence, suggest that the whole are coeval with the Monte Verde Formation. We have dated a plug intruding the Monte Verde Formation at $2.4 \pm 0.06 \mathrm{Ma}$ and another one within the LSVE at $4.1 \pm 0.1 \mathrm{Ma}$. Both ages correspond to the USVE time span.

São Vicente is one of the Cape Verde Islands where carbonatitic dikes and veinlets occur (Bebiano, 1932; Serralheiro, 1966). Hodgeson (1985) and Jorgensen and Holm (2002) considered the carbonatite intrusions as part of the early stage of the basaltic volcanism, the LSVE. Nevertheless we have also found carbonatites associated with nephelinites in the Monte Verde Formation. The carbonatitic rocks are especially seen in the lower section of that formation, so that they should be assigned to the USVE.

\subsection{Recent volcanics}

The recent volcanism of São Vicente is very scarcely represented and it is limited to a small number of strombolian cones from which lava flows were emitted to form land platforms gained from the sea. They appear in two separate sectors: in Bahia das Gatas and in Calhau situated respectively N and S of Praia Grande Bay (Figs. 4 and 17). Jorgensen and Holm (2002) have obtained an age of $0.33 \pm 0.05 \mathrm{Ma}$ for one of them. Besides, Trindade et al. (2003) have analysed the compositional characteristics of the lavas that correspond to olivine and pyroxene bearing basalts very different in alkalinity to the rest, more alkaline than the LSVE and less alkaline than the USVE rocks (Fig. 7d).

\section{Evolution of the island}

The oldest rocks in São Vicente are a remnants of the submarine edifice that at the present time crop out over sea level in the central sector of the island where the $\mathrm{BC}$, an ensemble of weathered and transformed volcanic and plutonic rocks crosscut by an intense dike network, underlies the SVE (Fig. 19a).

Most of the $\mathrm{BC}$ plutonic rocks are mildly and strongly alkaline gabbros, monzonites and syenites. The submarine rocks, intensely weathered greenish pre-SVE dikes associated with this stage show the same alkaline affinity (Fig. 7a).

The radiometric ages obtained for rocks in the $\mathrm{BC}$ ensemble give two separate groups of ages: one of them (6.5 and $5.3 \mathrm{Ma})$ is analogous to the ages obtained from the LSVE rocks ( 6.1 to $4.6 \mathrm{Ma}$ ), whilst the other one is notably older (about $9 \mathrm{Ma}$ ). The first group of ages can be interpreted as LSVE intrusive bodies and dikes. The second group should represent true submarine edifice ages or minimum ages for this edifice if the rocks were partially modified by later thermal events (i.e. intense diking).

The interpretation of the $\mathrm{BC}$ proposed by some authors (i.e. Bebiano, 1932; Serralheiro, 1966) as a composite volcano caldera (named Cha de Caldera or caldera-floor) partially invaded by the sea at Mindelo Bay, should be rejected. No sunken block of the edifice, but the remains of the previous edifice and the hypabyssal roots of the SVE are exposed in the $\mathrm{BC}$ area after have been exhumed by erosion. 


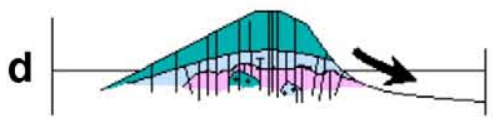

$4.5 \mathrm{Ma}$

$6-5.5 \mathrm{Ma}$

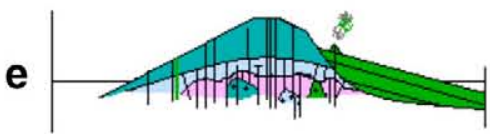

4-3 Ma

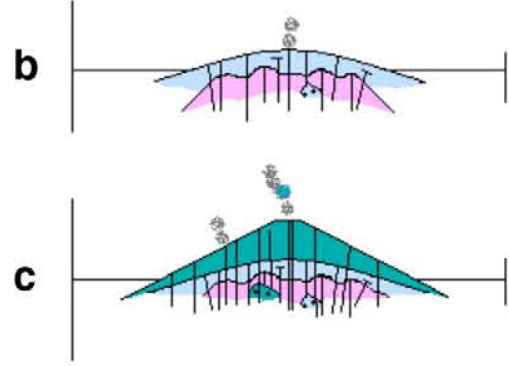

$5.5-4.5 \mathrm{Ma}$

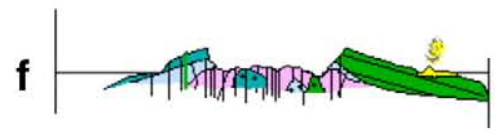

$0.3 \mathrm{Ma}$

Madeiral-Monte Cara Fm.
ITT Mindelo Formation
TITIT Basal Complex

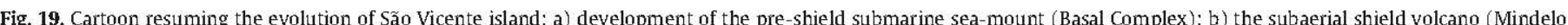

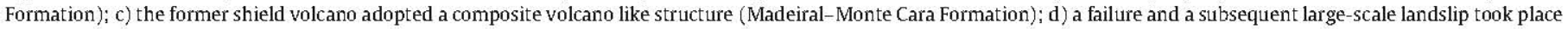

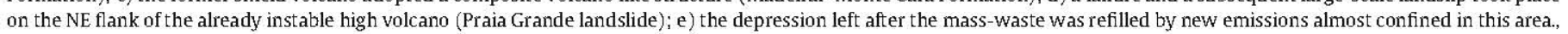
e) after a 2 million years long erosion period and a gap in activity a few strombolian eruptions occurred $\mathrm{E}$ and $\mathrm{NE}$ on the island.

In spite of a frequent apparent gradual transition between the Basal Complex and the São Vicente Edifice, somewhere in the south the SVE materials seem to cap a partially destroyed submarine edifice.

The São Vicente edifice arose in two main phases of construction (Fig. 19b and c). The early phase, building up the LSVE that took place between 6.1 and $4.6 \mathrm{Ma}$, initiated as a shield volcano (Mindelo Formation) that later turned into a composite volcano (MadeiralMonte Cara Formation). The resulting edifice as a whole acquired greater dimensions than the present island: $10-12 \mathrm{~km}$ in radius, at least $2500 \mathrm{~m}$ in height, and $300-400 \mathrm{~km}^{3}$ in volume. The main emission centre of the volcano, which was situated near the centre of the island, some $\mathrm{km}$ south of Mindelo Bay, migrated slightly with time along a south-southwest direction.

The composition of the LSVE rocks is essentially alkali basalts and basanites (Fig. 7b). The LSVE lava flows are crosscut by different families of dikes. The earlier family, as in La Gomera (Ancochea et al., 2006), is formed by sills emplaced basically through the lower sequence of the edifice (Mindelo Formation). The younger family of vertical or subvertical dikes follows radial patterns that make possible an estimation of the position of the main emission centre. The arrangement of these radial dikes is not entirely homogeneous because of the existence of several zones where the intrusion of dikes is much more intense. These zones might well define a three-armed rift pattern: $\mathrm{N} 20^{\circ}-30^{\circ}$; N $90^{\circ}-120^{\circ}$ and $\mathrm{N} 220^{\circ}-270^{\circ}$ more poorly defined (Figs. 11 and 14).

A relationship between rift zones and flank instability in ocean island volcanoes has often been inferred (i.e.: Dieterich, 1988; Carracedo, 1994, 1999; Carracedo et al., 1999; Stillman, 1999; Walter and Schmincke, 2002). The presence of surtseyan pyroclastic layers at the transition from the submarine to the subaerial edifice, may also favour the collapse (i.e.: La Reunion and Kilauea, Duffield et al., 1982; La Palma, Ancochea et al., 1994).

In the present case, firstly the important height of the SVE, secondly the localization of the landslide between two of the possible rifts $\left(\mathrm{N} 20^{\circ}\right.$ and $\mathrm{N} 110^{\circ}$ ) and thirdly the fact that the post-landslide deposits in the innermost zone rest upon the submarine edifice materials may either separately or altogether have favoured the Praia Grande lateral collapse.
The Praia Grande landslide occurred 4.5 million years ago resulting in eastward displacement of an approximate volume of $90 \mathrm{~km}^{3}$ of rocks that created a $12 \mathrm{~km}$ wide and about $10 \mathrm{~km}$ long depression (Fig. 19d).

In Cape Verde the main giant landslide event known by using recognizable features on land is found on the island of Fogo (Day et al., 1999; Elsworth and Day, 1999). In the light of submarine data Le Bas et al. (2007) and Masson et al. (2008) have analysed large-scale landsliding processes in Cape Verde and identified several of these kind of events not only in Fogo but also in Santo Antao (four events) and in São Nicolau (two events).

These authors did not find evidence of landslide deposits on the northern smooth lower submarine slope of São Vicente, where the Praia Grande landslide should necessarily be recorded. Due to the old age of the collapse event proposed in this paper, the existence of morphological scarps in the slope, or else the presence of landslide deposits offshore could be obliterated and then difficult to be recognized. The same authors even indicate that "concentrations of canyons on the upper slope may thus be an additional feature that can be used to identify old landslides, even when the morphology of the slope has been modified to an extent where even slope profiles cannot be used for this purpose". Since Masson et al. (2008) mark the presence of some submarine canyons in that sector, this fact might be a remaining sign of the Praia Grande landslide, notwithstanding a revision of the data is necessary in order to identify the submarine trace of the landslide.

In contrast, Masson et al. (2008) interpret a bulge in the bathymetric contours and a speckled character in backscatter maps on the lower SW slope of São Vicente, as an area of relatively old landslide deposits. Though we have not found evidence on land of this hypothetical landslide, the absence of the Madeiral-Monte Cara Formation in the SW, its location in between two arms of the probable three-armed rift, plus the existence of some minor unconformities near the top of LSVE scarp in this area, might well be signs that could support the existence of this event (Fig. 14).

It is feasible as well that the emphasized morphological inlets in the island contour of São Vicente are related to landslide processes. This seems to be evident in Praia Grande Bay. The one suggested in the SW sector and identified offshore by Masson et al. (2008) could be 
related to San Pedro Bay and perhaps, even Mindelo Bay could be a trace of one more lateral collapse thought no signs, neither onshore or offshore, have been yet recognized.

The second main growth stage, the USVE (Fig. 19e), consisted essentially of a refilling of the depression generated by the Praia Grande landslide, a stage that occurred between 4.5 and $3.1 \mathrm{Ma}$, though minor local felsic activity may have gone on until more recent times (2.4 Ma). It is probable that this volcanic activity also took place outside the depression of Praia Grande, but except for some scarce plugs, as for instance Monte Passarinho, close to San Pedro Bay far from the depression, no other evidence is preserved.

This same stage undergone by the SVE supposes a drastic change in magma composition from alkaline turning to ultra alkaline or strongly alkaline nature, including differentiated members that range from nepheline tephrites to nepheline phonolites (Fig. 7). As elsewhere, for instance in Tenerife, the decompression created by collapse might have favoured either mantle melting (Navarro and Coello, 1989) to a greater depth and with a lesser degree of partial melting, or melting from a different mantle source (Jorgensen and Holm, 2002). The increase in alkalinity of the magmas could be a consequence of a greater depth, a lesser melting degree or both.

The materials that refilled the depression, the Monte Verde Formation, are exposed at the present time as an inverted relief in which the refilling deposits give a prominent relief whilst in both the ancient lateral scarps of the depression the subsequent erosion has excavated two valleys: Ribeira de Calhau in the south, and Ribeira de Joao Evora in the north.

The headwall of the original depression has experienced a certain retreat after erosion. Some nephelinitic and phonolitic plugs or small ijolitic intrusions observed in the $\mathrm{BC}$ and in the lowermost levels of the Monte Verde Formation represent roots of the USVE materials. Also some carbonatitic dikes and veinlets associated with them must be viewed altogether with those rocks and not as part of a previous magmatic phase.

The abundance of pyroclastics is significantly greater in the USVE with respect to the LSVE, nevertheless no felsic pyroclastic levels have been found as should be expected given the presence of phonolitic magmatism. The breccias deposits intercalated near the top of Monte Verde are a reflection of noticeable destructive events that also affected the USVE. In the same manner, the local breccias appearing at different levels in the LSVE evidence that, with different intensity, destructive events acted almost during the entire growth of São Vicente.

The depression was filled by materials dipping uniformly seaward (Monte Verde Formation), in a similar way to the events which occurred in La Orotava Valley in Tenerife. Nevertheless some differences are recorded between these two localities since in La Orotava the refilling occurred more recently in the last $0.6 \mathrm{Ma}$ (Ancochea et al., 1990). Contrarily, the emissions of the Monte Verde Formation, which started more than 4 million years ago crop out at present as an inversion of relief. The south edge is the area where this relief is better expressed by a valley, Ribeira de Calhau, which marks the ancient scarp of the palaeo-depression. The valley marking the corresponding contact on the north edge, Ribeira de Joao Evora, is more poorly defined.

The scarce recent volcanism ( $0.33 \mathrm{Ma}$, Fig. 19e) took place after an important gap in activity of 2 million years. The renewed activity differs from the previous one in extension and composition. Holm et al. (2008) related this young activity to the possibly coeval activity on Santo Antao or as well to that which occurred on some of the smaller islands and islets. Notwithstanding the recent volcanism of São Vicente is less alkaline than the contemporaneous rocks of Santa Luzia and Raso (Ancochea et al., in prep.).

In summary, the island of São Vicente can basically be considered as a single subaerial volcanic complex, the São Vicente Edifice, essentially Pliocene in age emerging on top of a submarine edifice of possible Upper
Miocene age. A remarkable landslide destroyed a large volume of the complex in its eastern flank, modifying considerably the previous morphology and giving rise to a new constructive stage during which, the depression created after the lateral collapse was refilled by very different more alkaline lavas and some associated carbonatites. The activity ceased completely in the Pliocene when long erosive processes started the dismantling of the São Vicente edifice.

\section{Acknowledgements}

The Projects BTE 2003-02153, CGL2006-03414, CGL2009-07946 and G.I. 910469 UCM-CAM supported this work. The authors thank C. J. Stillman and an anonymous referee for their constructive remarks. Prof. Allister Horbury revised the English version of the manuscript.

\section{References}

Ancochea, E., Fúster, J.M., Ibarrola, E., Cendrero, A, Coello, J., Hernán, F., Cantagrel, J.M., Jamond, C., 1990. Volcanic evolution of the island of Tenerife (Canary Islands) in the light of new K-Ar data. J. Volcanol. Geotherm. Res. 44, 231-249.

Ancochea, E., Cubas, C.R., Hernán, F., Brändle, J.L., 1991. Edificios volcánicos en la Serie I de Fuerteventura: rasgos generales de1 Edificio Central. Geogaceta 9, 60-62.

Ancochea, E., Hernán, F., Cendrero, A., Cantagrel, J.M., Fúster, J.M., Ibarrola, E., Coello, J. 1994. Constructive and destructive episodes in the building of a young oceanic island, La Palma, Canary Islands, and genesis of the Caldera de Taburiente. J. Volcanol. Geotherm. Res. 60, 243-262.

Ancochea, E., Brändle, J.L., Cubas, C.R., Hernán, F., Huertas, M.J., 1996. Volcanic complexes in the eastern ridge of the Canary Islands: the Miocene activity of the island of Fuerteventura. J. Volcanol. Geotherm. Res. 70, 183-204.

Ancochea, E., Brändle, J.L., Huertas, M.J., Cubas, C.R., Hernán, F., 2003. The felsic dikes of La Gomera (Canary Islands): identification of cone sheet and radial dike swarms. J. Volcanol. Geotherm. Res. 120, 197-206.

Ancochea, E., Hernán, F., Huertas, M.J., Brändle, J.L., Herrera, R., 2006. A new chronostratigraphy and evolutionary model for La Gomera in the framework of the Canarian archipelago. J. Volcanol. Geotherm. Res. 157, 271-293.

Ancochea, E., Brändle, J.L., Huertas, M.J., Hernán, F., Herrera, R., 2008. Dike-swarms, key to the reconstruction of major volcanic edifices: the basic dikes of La Gomera (Canary Islands). J. Volcanol. Geotherm. Res. 173, 207-216.

Bebiano, J., 1932. A Geologia do Arquipélago de Cabo Verde: Com. Serv. Geol. Portugal, 18. $276 \mathrm{pp}$.

Brändle, J.L., Ancochea, E., Cubas, C.R., Hernán, F., 1991. Análisis de enjambres de diques radiales utilizando un método matemático. Geogaceta 10, 97-100.

Cantagrel, J.M., Cendrero, A., Fúster, J.M., Ibarrola, E., Jamond, C., 1984. K-Ar chronology of the volcanic eruption in the Canarian Archipelago: island of La Gomera. Bull. Volcanol. 47, 597-609.

Carracedo, J.C., 1994. The Canary Islands: an example of structural control on the growth of large oceanic-island volcanoes. J. Volcanol. Geotherm. Res. 60, 225-241.

Carracedo, J.C., 1999. Growth, structure, instability and collapse of Canarian volcanoes and comparison with Hawailan volcanoes. J. Volcanol. Geotherm. Res. 94, 1-19.

Carracedo, J.C., Day, S.J., Guillou, H., Perez Torrado, F.J., 1999. Giant Quaternary landslides in the evolution of La Palma and El Hierro, Canary Islands. J. Volcanol. Geotherm. Res. 94, 169-190.

Christensen, B.P., Holm, P.M., Jambon, A., Wilson, J.R., 2001. Helium, argon and lead isotopic composition of volcanics from Santo Antao and Fogo, Cape Verde islands. Chem. Geol. 178, 127-142.

Dalrymple, G.B., Lanphere, M.A., 1969. Potassium-Argon Dating: Principles, Techniques and Applications to Geochronology. W.H. Freeman and Co, San Francisco. 258 pp.

Dash, B.P., Ball, M.M., King, G.A., 1976. Geophysical investigations of the Cape Verde archipelago. J. Geophys. Res. 81, 5249-5259.

Davies, G.R., Norry, M.J., Gerlach, D.C., Cliff, R.A., 1989. A combined chemical and Pb-SrNd isotope study of the Azores and Cape Verde hotspots. In: Saunders, A.D., Norry, M.J. (Eds.), The Geodynamic Implications Magmatism in the Ocean Basins: Geol. Soc. London, pp. 231-255.

Day, S.J., Heleno, S.I.N., Fonseca, J.F., 1999. A past giant lateral collapse and present-day flank instability of Fogo, Cape Verde Islands. J. Volcanol. Geotherm. Res. 94, $191-218$

De Paepe, P., Klerkx, J., Herton, J., Plinke, P., 1974. Oceanic tholeiites on the Cape Verde islands: petrochemical and geochemical evidence. Earth Planet. Sci. Lett. 22, 347-354.

Dieterich, J.H., 1988. Growth and persistence of Hawaiian volcanic rift zones. J. Geophys. Res. 93, 4258-4270.

Doucelance, R., Escrig, S., Moreira, M., Gariepy, C., Kurz, M.D., 2003. Pb-Sr-He isotope and trace element geochemistry of the Cape Verde Archipelago. Geochim. Cosmochim. Acta 67, 3717-3733.

Duffield, W.A., Stieltjes, L., Varet, J., 1982. Huge landslide blocks in the growth of Piton de la Fournaise, La Reunion, and Kilauea, Hawaii. J. Volcanol. Geotherm. Res. 12, 147-160.

Dyhr, Ch.T., Holm, P.M., 2010. A volcanological and geochemical investigation of Boa Vista Cape Verde Islands; ${ }^{40} \mathrm{Ar} /{ }^{\beta 9} \mathrm{Ar}$ geochronology and field constraints. J. Volcanol. Geotherm. Res. 189, 19-32.

Elsworth, D., Day, S.J., 1999. Flank collapse triggered by intrusion: the Canarian and Cape Verde archipelagos. J. Volcanol. Geotherm. Res. 94, 323-340. 
Escrig, S., Doucelance, R., Moreira, M., Allegre, C.J., 2005. Os isotope systematics in Fogo Island; evidence for lower continental crust fragments under the Cape Verde southern islands. Chem. Geol. 219 (1-4), 93-113.

Feraud, G., Giannerini, G., Campredon, R., Stillman, C.J., 1985. Geochronology of some Canarian dike swarms: contribution to the volcano-tectonic evolution of the archipelago. J. Volcanol. Geotherm. Res. 25, 29-52.

Fúster, J.M., Cendrero, A., Gastesi, P., Ibarrola, E., López Ruiz, J., 1968. Geology and Volcanology of Canary Islands, Fuerteventura. Inst. Lucas Mallada, C.S.I.C., Madrid. 243pp.

Griffiths, J., Cantagrel, J.M., Alves, A., Mendes, F., Serralheiro, A., Macedo, J., 1975. Données radiometriques potassium-argon sur quelques formations magmatiques des iles de l'archipel du Cap Vert. C. R. Acad. Sci. Paris 280, 2429-2432.

Hodgeson, N.A., 1985. Carbonatites and associated rocks from the Cape Verde Islands. PhD Thesis, University of Leicester, $271 \mathrm{pp}$.

Holcomb, R., Searle, R., 1991. Large landslide from oceanic volcanoes. Mar. Geotechnol $10,19-32$.

Holm, P.M., Wilson, J.R., Christensen, B.P., Hansen, L., Hansen, S.L., Hein, K.M. Mortensensen, A.K., Pedersen, R., Plesner, S., Runge, M.K., 2006. Sampling the Cape Verde mantle plume: evolution of melt composition on Santo Antao, Cape Verde Islands. J. Petrol. 47, 145-189.

Holm, P.M., Grandvuinet, T., Friis, J., Wilson, J.R., Barker, A.K., Plesner, S., 2008. An ${ }^{40} \mathrm{Ar}^{-39}{ }^{39}$ study of the Cape Verde hot spot: temporal evolution in a semistationary plate environment. J. Geophys. Res. 113 (B-8), B08201. doi:10.1029/2007JB005339.

Huertas, M.J., Hernán, F., Ancochea, E., Brändle, J.L., 2006. El Edificio Antiguo de la isla de San Vicente (Cabo Verde): características del sector occidental. Geogaceta 40 , 95-98.

Jorgensen, J.O., Holm, P.M., 2002. Temporal variation and carbonatite contamination in primitive ocean island volcanics from São Vicente, Cape Verde Islands. Chem. Geol. $192,249-267$.

Krastel, S., Schmincke, H.-U., Jacobs, C.L., Rihm, R., Le Bas, T.P., Alibés, B., 2001. Submarine landslides around the Canary Islands. J. Geophys. Res. 106, 3977-3998.

Le Bas, T.P., Masson, D.G., Holtom, R.T., Grevemeyer, I., 2007. Slope failures on the flanks of the southem Cape Verde Islands. In: Lykousis, V., Sakellariou, D., Locat, J. (Eds.), Submarine Mass Movements and Their Consequences. Springer-Verlang, Dordrecht, Netherlands, pp. 337-345.

Machado, F., Torre de Assuncao, C.F., 1965. Carta geológica de Cabo Verde (Folha da ilha do Fogo). Garcia de Orta 13, 597-604.

Machado, F., Leme, J., Mojardino, J., Seita, M.F., 1968. Carta geologica de Cabo Verde, noticia explicativa da folha da ilha Brava e dos ilheus Secos (na escala 1/5000). Garcia de Orta 16, 123-130.

Masson, D.G., Watts, A.B., Gee, M.J.R., Urgeles, R., Mitchell, N.C., Le Bas, T.P., Canals, M., 2002. Slope failures on the flanks of the western Canary Islands. Earth Sci. Rev. 57, $1-35$.
Masson, D.G., Le Bas, T.P., Grevemeyer, I., Weinrebe, W., 2008. Flank collapse and largescale landsliding in the Cape Verde Islands, off West Africa. Geochem. Geophys. Geosyst. 9, Q07015. doi:10.1029/2008GC001983.

Mitchell, J., Le Bas, M.J., Zielonka, J., Furnes, H., 1983. On dating the magmatism of Maio, Cape Verde Islands. Earth Planet. Sci. Lett. 64, 61-76.

Mitchell-Thomé, R.C., 1976. Geology of the Middle Atlantic Islands. Gebrüder Borntraeger, Berlin. 325 pp.

Navarro, J.M., Coello, J., 1989. Depressions originated by landslide processes in Tenerife European Science Foundation Meeting on Canarian Volcanism, Cabildo insular de Lanzarote, Abstract, pp. 150-152.

Peterson, D.W., Moore, R.B., 1987. Geologic history and evolution of geologic concepts, island of Hawaii. In: Decker, R.W., Wright, T.L, Stauffer, P.H. (Eds.), Volcanism in Hawaii: U.S. Geol. Surv., Prof. Pap., 1350, pp. 149-189.

Plesner, S., Holm, P., Wilson, J., 2002. ${ }^{40} \mathrm{Ar}-{ }^{39} \mathrm{Ar}$ geochronology of Santo Antao, Cape Verde Islands. J. Volcanol. Geotherm. Res. 118, 1-19.

Serralheiro, A., 1966. Contribuçao para o conhecimiento da ilha de S. Vicente (Cabo Verde). Garcia de Orta 14, 139-152.

Serralheiro, A., 1970. Geologia da Ilha de Maio (Cabo Verde). Junta de Invest. do Ultramar, Lisboa. 103 pp.

Serralheiro, A. 1976. A geologia da Ilha de Santiago (Cabo Verde). Bol. Mus. Lab. Min. Geol. Fac. Cienc. 14, 1-157.

Stillman, C.J., 1999. Giant Miocene landslides and the evolution of Fuerteventura, Canary Islands. J. Volcanol. Geotherm. Res. 94, 89-104.

Stillman, C.J., Fúster, J.M., Bennell Baker, M.J., Muñoz, M., Smewing, J.D., Sagredo, J., 1975. Basal complex of Fuerteventura is an oceanic intrusive complex with rift-system affinities. Nature 257, 469-470.

Stillman, C.J., Furnes, H., Le Bas, M.J., Robertson, A.H.F., Zielonka, J., 1982. The geological history of Maio, Cape Verde Islands. J. Geol. Soc. 139, 347-361.

Torre de Assunçao, C.F., Canilho, M.H.S., 1965. Petrografia da ilha de S.Vicente: novos elementos para o seu conhecimiento. García de Orta 13, 235-258.

Torre de Assunçao, C.F., Machado, F., Silva, L, 1967. Petrologia e vulcanismo da ilha do Fogo (Cabo Verde). Garcia de Orta 15, 99-110.

Torres, P.C., Silva, L.C., Serralheiro, A., Tassinari, C., Munha, J., 2002. Enquadramento geocronologico pelo metodo $\mathrm{K} / \mathrm{Ar}$ das principais sequencias vulcano-estratigraficas da Ilha do Sal; Cabo Verde. Garcia de Orta, Ser. Geol. 18, 9-13.

Trindade, M.J., Mata, J., Munhá, J., 2003. Petrogenesis of Quaternary magmatism in S. Vicente Island (Cape Verde). Comun. Serv. Geol. Min. 90, 169-188.

Walter, T.R., Schmincke, H.U., 2002. Rifting, recurrent landsliding and Miocene structural reorganization on NW-Tenerife (Canary Islands). Int. J. Earth Sci. 91, 615-628. 